\title{
Supplementary information for Photochemical Aging of Atmospheric Particulate Matter in the Aqueous Phase
}

Frank Leresche ${ }^{1,2, *}$, Joseph R. Salazar ${ }^{3}$, David J. Pfotenhauer ${ }^{4}$, Michael P. Hannigan ${ }^{4}$, Brian J. Majestic ${ }^{3}$, Fernando L. Rosario-Ortiz ${ }^{1,2}$

${ }^{1}$ Department of Civil, Environmental and Architectural Engineering, University of Colorado at Boulder, Boulder, 80309, USA ${ }^{2}$ Environmental Engineering Program, University of Colorado Boulder, Colorado 80309, USA

${ }^{3}$ Department of Chemistry and Biochemistry, University of Denver, Denver, 80208, USA

${ }^{4}$ Department of Mechanical Engineering, University of Colorado at Boulder, Boulder, 80309, USA

*Correspondence to Frank Leresche (Frank.Leresche@Colorado.edu)

Number of pages: 27

Number of text sections: $\quad 7$

Number of figures: $\quad 9$

Number of tables: $\quad 10$ 
Table of content for the supplementary information

S3 Figure S1. Map of the sampling sites

S4 Figure S2. Wind roses during the sampling campaign

S5 Table S1. Data for the sampling campaign samples

S7 Table S2. Characteristics of the aqueous extracts

S9 Table S3. Characteristics of the aqueous extracts and of the blanks

S10 Figure S3. Solar simulator photon irradiance spectra

S11 Figure S4. Experiment cuvette UV-Vis absorbance and transmittance spectra

S12 Text S1. Chemical Actinometer

S12 Text S2. Singlet oxygen $\left({ }^{1} \mathrm{O}_{2}\right)$ measurements

S12 Text S3. Hydroxyl radical ( $\left.{ }^{\circ} \mathrm{OH}\right)$ measurements

S13 Table S4. High Performance Liquid Chromatography (HPLC) methods

S14 Text S5. Chemicals used in the experiments

S14 Figure S5. Effects of photoaging on the optical characteristics of the $\mathrm{PM}_{2.5}$ aqueous extracts

S15 Figure S6. Fluorescence excitation emission matrices (EEMs) of the spring $\mathrm{PM}_{2.5}$ extracts

S16 Figure S7. Fluorescence excitation emission matrices (EEMs) of the summer $1 \mathrm{PM}_{2.5}$ extracts

S17 Figure S8. Fluorescence excitation emission matrices (EEMs) of the summer $2 \mathrm{PM}_{2.5}$ extracts

S18 Table S5. Mean fluorescence quantum yield $\left(\Phi_{\mathrm{F}}\right)$

S19 Text S6. Analysis of the hydroxyl radical $\left({ }^{\circ} \mathrm{OH}\right)$ reaction with atmospheric waters soluble organic carbon (WSOC)

S20 Table S6. Hydroxyl radical ( $\left({ }^{\circ} \mathrm{OH}\right)$ reactivity towards atmospheric waters dissolved carbon and model compounds

S21 Figure S9. Rate of hydroxyl radical production $(r \cdot \mathrm{OH})$ as a function of the ions composition of the extracts

S22 Text S7. Pre-equilibrium approximation for the calculation of the rate constant between ${ }^{\circ} \mathrm{OH}$ and chloride or bromide.

S23 Table S7. Decomposition of the ${ }^{\circ} \mathrm{OH}$ reaction with the components of the summer extracts (mean)

S23 Table S8. Decomposition of the ${ }^{\circ} \mathrm{OH}$ reaction with the components of the summer extracts.

S24 Table S9. Singlet oxygen steady state $\left(\left[{ }^{1} \mathrm{O}_{2}\right]_{\mathrm{ss}}\right)$, quantum yield $\left(\Phi_{1 \mathrm{O} 2}\right)$ and hydroxyl radical steady-state $\left(\left[{ }^{\circ} \mathrm{OH}\right]_{\mathrm{ss}}\right)$

S26 Table S10. Calculations of $f_{102}$, and half-lives of compounds

S27 Bibliography 
Figure S1. Map of the sampling sites (red circles) and of the wind measurement stations (yellow circles).

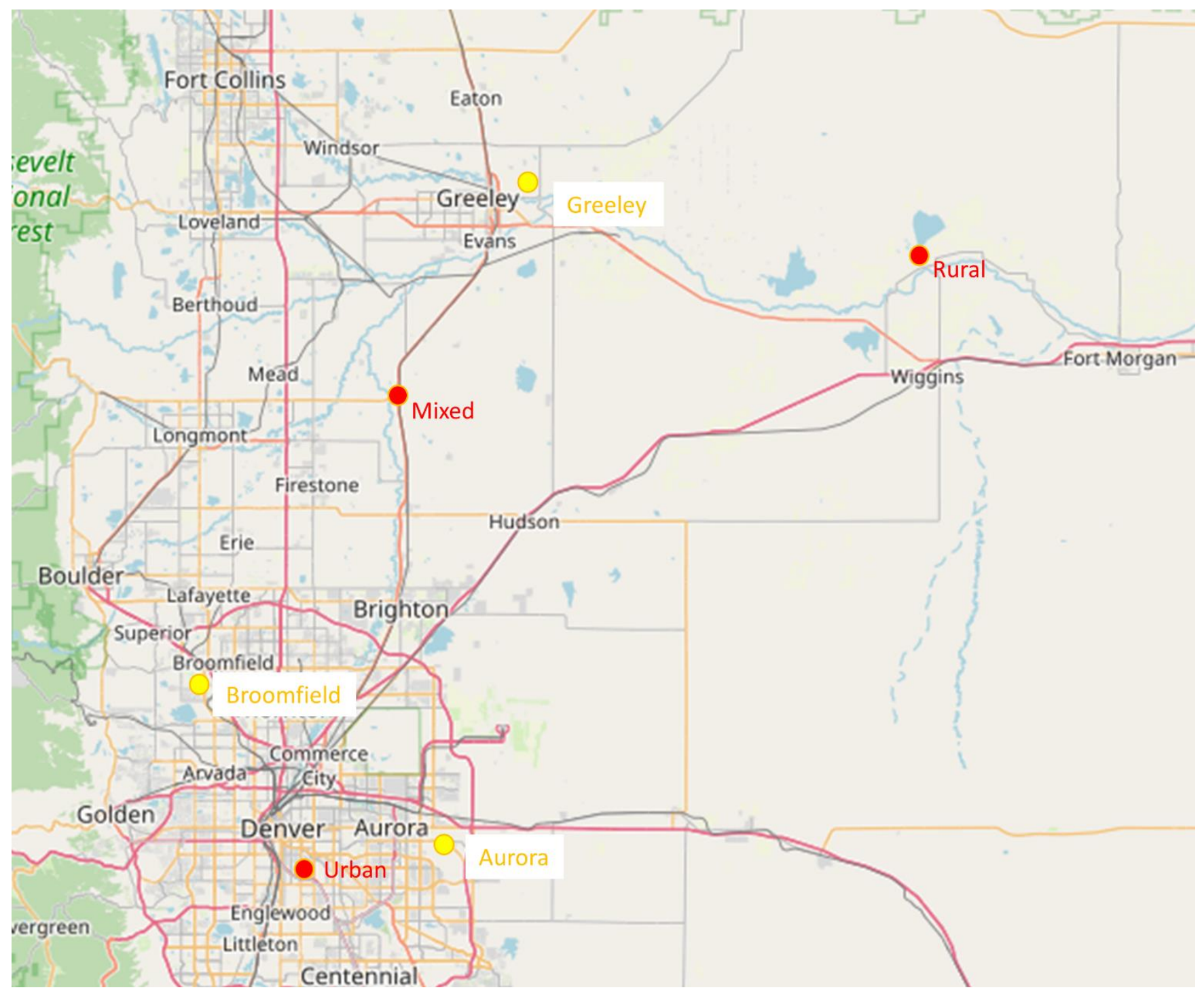

Map data: () OpenStreetMap contributors. 
Figure S2. Wind roses during the sampling campaign. See Figure S1 for the location of the wind measurement stations.

AURORA BUCKLEY FLD ANGB (CO) Wind Rose Dec. 11, $2016-$ Dec. 24,2016
Sub-Interval. Jan. 1- Dec. $31,0-23$
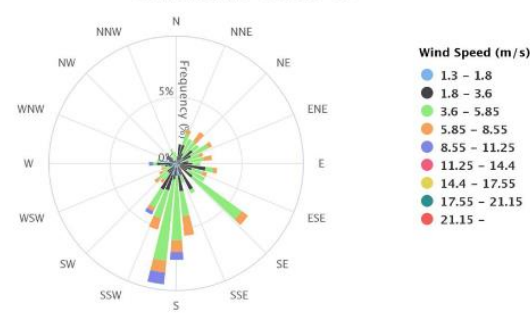

AURORA BUCKLEY FLD ANGB (CO) Wind Rose Heb. 13, $2017-$ Apr. 21, 2017
Sub-lnterval Jan, 1- 1 Dec. 31, $0-23$

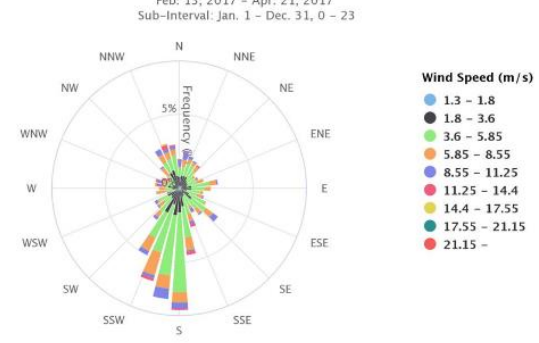

AURORA BUCKLEY FLD ANGB (CO) Wind Rose Aug. 3, 2017- Aug. 23, 2017
Sub-Interval Jan. 1 - Dec. 31, $0-23$

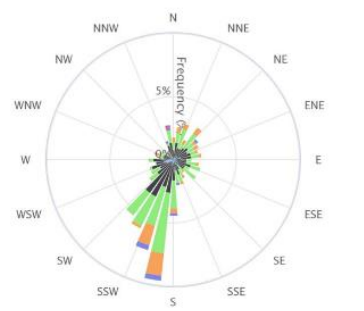

BROOMFIELD JEFFERSON CO AP (CO) Wind Rose Dec, $11,2016-$ Dec, 24,2016
Sub-Interval Jan. 1 - Dec, $31,0-23$

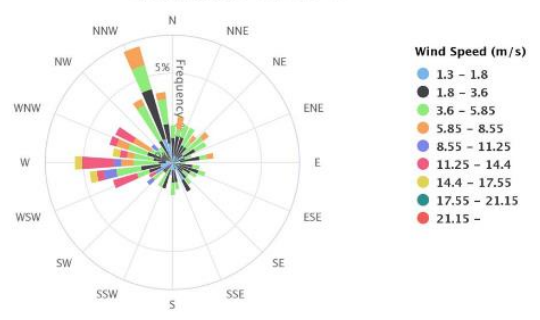

BROOMFIELD JEFFERSON CO AP (CO) Wind Rose

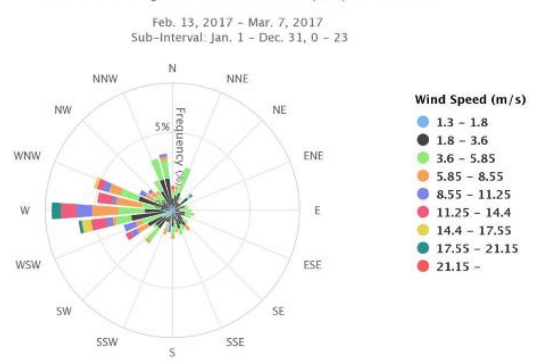

BROOMFIELD JEFFERSON CO AP (CO) Wind Rose Aug. 3, 2017 - Aug. 23, 2017
Sub-Interval: Jan. 1 - Dec, 31, $0-23$
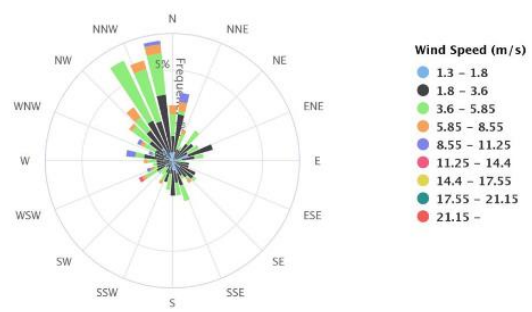

GREELEY WELD CO AP (CO) Wind Rose Dec, 11, $2016-$ Dec, 24,2016
sub-Interval Jan. 1 - Dec, $31,0-23$

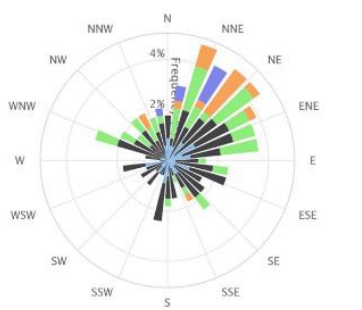

$1.3-1.8$ $1.8-3.6$ $5.85-8.55$
$8.55-11.25$ $11.25-14.4$
$14.4-17.55$
$1.55-21.15$ $14.4-17.55$
$21.15-21.15$
-

GREELEY WELD CO AP (CO) Wind Rose Feb. 13, $2017-$ Mar. 7, 2017
Sub-Interval Jan. 1 - Dec. 31, $0-23$

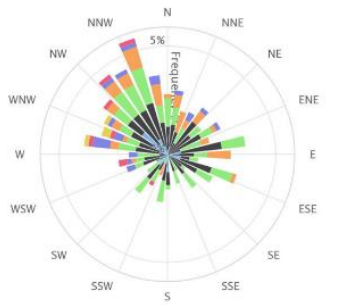

Wind Speed $(m / s)$ $1.3-1.8$
$-1.8-3.6$ $1.8-3.6$
$3.6-5.85$
$5.85-8.55$ $5.85-8.55$
$8.55-11.25$ $11.25-14.4$ $14.4-17.55$

GREELEY WELD CO AP (CO) Wind Rose Aug. 3, 2017- Aug. 23, 2017
Sub-lnterval Jan. 1 - Dec. $31,0-23$

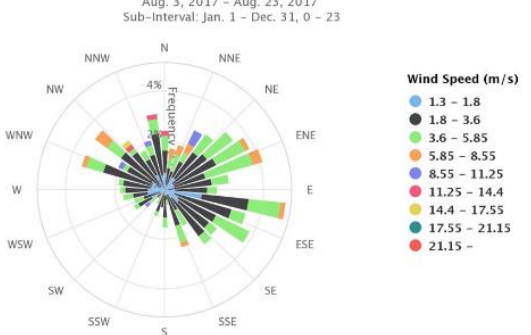

Data from the Midwestern Regional Climate Center: https://www.climate.gov/maps-data/dataset/wind-roses-charts-and-tabular-data 
Table S1. Data for the sampling campaign samples.

Name $^{a} \quad$ Site Date collected $\quad$ Volume collected $/ \mathrm{m}^{3} \quad \mathrm{EC}+\mathrm{OC} / \mu \mathrm{g} \mathrm{m}{ }^{-3}$

\begin{tabular}{|c|c|c|c|c|}
\hline PR 01 TEF & CAMP & blank & & \\
\hline PR 02 TEF & CAMP & 11.12 .2016 & 121.6 & 2.78 \\
\hline PR 03 TEF & CAMP & 19.12 .2016 & 131.3 & 4.59 \\
\hline PR 04 TEF & CAMP & 21.12 .2016 & 121.9 & 3.43 \\
\hline PR 05 TEF & CAMP & 23.12 .2016 & n.d. & n.d. \\
\hline PR 06 TEF & CAMP & 17.12 .2016 & 126.1 & 4.86 \\
\hline PR 07 TEF & CAMP & 13.12 .2016 & 130.7 & 5.52 \\
\hline PR 08 TEF & CAMP & 15.12 .2016 & 126.6 & 5.62 \\
\hline PR 09 TEF & Jackson & 13.12 .2016 & 104.4 & n.d. \\
\hline PR 10 TEF & Jackson & 21.12 .2016 & n.d. & 0.88 \\
\hline PR 11 TEF & Jackson & 15.12 .2016 & n.d. & 1.98 \\
\hline PR 12 TEF & Jackson & 17.12 .2016 & 117.1 & 4.41 \\
\hline PR 13 TEF & Jackson & 11.12 .2016 & 60.3 & 2.57 \\
\hline PR 14 TEF & Jackson & blank & & \\
\hline PR 15 TEF & Jackson & 19.12 .2016 & n.d. & 4.47 \\
\hline PR 16 TEF & Jackson & 23.12 .2016 & n.d. & 1.17 \\
\hline PR 17 TEF & Platteville & blank & & \\
\hline PR 18 TEF & Platteville & 13.12 .2016 & 128.2 & 0.79 \\
\hline PR 19 TEF & Platteville & 15.12 .2016 & 125.8 & 1.24 \\
\hline PR 20 TEF & Platteville & 17.12 .2016 & 124.8 & 1.29 \\
\hline PR 21 TEF & Platteville & 21.12.2016 & 128.8 & 1.08 \\
\hline PR 22 TEF & Platteville & 23.12 .2016 & 119.5 & 3.14 \\
\hline PR 45 TEF & CAMP & blank & & \\
\hline PR 43 TEF & CAMP & 24.02 .2017 & 129.6 & 1.80 \\
\hline PR 30 TEF & CAMP & 26.02.2017 & 130.3 & 2.11 \\
\hline PR 32 TEF & CAMP & 28.02 .2017 & 132.4 & 3.47 \\
\hline PR 26 TEF & CAMP & 02.03.2017 & 131.6 & 1.92 \\
\hline PR 35 TEF & CAMP & 07.03 .2017 & 129.2 & 4.17 \\
\hline PR 31 TEF & Jackson & blank & & \\
\hline PR 48 TEF & Jackson & 24.02 .2017 & 129.4 & 1.66 \\
\hline PR 46 TEF & Jackson & 26.02.2017 & 129.7 & 1.25 \\
\hline PR 25 TEF & Jackson & 28.02.2017 & 132.1 & 0.86 \\
\hline PR 33 TEF & Jackson & 02.03 .2017 & 133.0 & 0.72 \\
\hline PR 47 TEF & Jackson & 07.03 .2017 & 132.1 & 1.66 \\
\hline PR 27 TEF & Platteville & blank & & \\
\hline PR 42 TEF & Platteville & 24.02.2017 & 129.4 & 0.61 \\
\hline PR 29 TEF & Platteville & 26.02.2017 & 129.0 & 1.37 \\
\hline PR 39 TEF & Platteville & 28.02 .2017 & 131.2 & 1.82 \\
\hline PR 40 TEF & Platteville & 02.03 .2017 & 130.9 & 1.24 \\
\hline PR 41 TEF & Platteville & 07.03 .2017 & 131.9 & 2.88 \\
\hline PRS 13 TEF & Jackson & 03.08.2017 & 138.1 & 2.65 \\
\hline
\end{tabular}




\begin{tabular}{|c|c|c|c|c|}
\hline PRS 20 TEF & Jackson & 05.08 .2017 & 136.9 & 4.11 \\
\hline PRS 46 TEF & Jackson & 07.08 .2017 & 136.9 & 3.30 \\
\hline PRS 49 TEF & Jackson & 09.08.2017 & 136.5 & 2.63 \\
\hline PRS 03 TEF & Jackson & 11.08.2017 & 146.0 & 2.81 \\
\hline PRS 24 TEF & Platteville & 03.08.2017 & 137.8 & 3.07 \\
\hline PRS 38 TEF & Platteville & 05.08.2017 & 137.2 & 4.42 \\
\hline PRS 44 TEF & Platteville & 07.08 .2017 & 137.3 & 3.17 \\
\hline PRS 18 TEF & Platteville & 09.08.2017 & 136.2 & 3.65 \\
\hline PRS 22 TEF & Platteville & 11.08 .2017 & 57.0 & n.d. \\
\hline PRS 50 TEF & CAMP & 03.08.2017 & 50.2 & 4.41 \\
\hline PRS 30 TEF & CAMP & 05.08.2017 & 90.2 & 6.69 \\
\hline PRS 17 TEF & CAMP & 07.08.2017 & 92.8 & 4.09 \\
\hline PRS 47 TEF & CAMP & 09.08.2017 & 95.3 & 4.15 \\
\hline PRS 40 TEF & CAMP & 11.08 .2017 & 96.1 & 4.36 \\
\hline PRS 26 TEF & Jackson & 13.08 .2017 & 147.0 & 2.54 \\
\hline PRS 7 TEF & Jackson & 15.08.2017 & 135.9 & 1.98 \\
\hline PRS 9 TEF & Jackson & 17.08 .2017 & 136.6 & 3.12 \\
\hline PRS 8 TEF & Jackson & 21.08.2017 & 136.4 & 3.81 \\
\hline PRS 2 TEF & Jackson & 23.08 .2017 & 136.1 & 3.22 \\
\hline PRS 23 TEF & Platteville & 13.08.2017 & 137.5 & 2.47 \\
\hline PRS 5 TEF & Platteville & 15.08 .2017 & 139.2 & 2.54 \\
\hline PRS 14 TEF & Platteville & 17.08.2017 & 138.2 & 2.52 \\
\hline PRS 37 TEF & Platteville & 21.08 .2017 & 140.2 & 3.95 \\
\hline PRS 32 TEF & Platteville & 23.08 .2017 & 138.4 & 4.05 \\
\hline PRS 31 TEF & CAMP & 13.08.2017 & 90.6 & 3.64 \\
\hline PRS 36 TEF & CAMP & 15.08 .2017 & 96.6 & 3.09 \\
\hline PRS 34 TEF & CAMP & 17.08 .2017 & 82.5 & 2.95 \\
\hline PRS 41 TEF & CAMP & 21.08.2017 & 94.8 & 3.57 \\
\hline PRS 42 TEF & CAMP & 23.08 .2017 & 98.4 & 5.89 \\
\hline
\end{tabular}

Note: ${ }^{a}$ PR refers to the name of the sampling campaign (PRAPPE) and PRS refers to PRAPPE Summer. 
Table S2. Characteristics of the aqueous extracts ${ }^{a}$

\begin{tabular}{|c|c|c|c|c|c|c|c|c|c|c|c|c|c|}
\hline Name $^{b}$ & $\begin{array}{c}\text { Carbon } \\
\text { extraction } \\
\text { efficiency } \\
/ \%^{c}\end{array}$ & $\begin{array}{l}\text { Dilution } \\
\text { factor }^{d}\end{array}$ & $\begin{array}{c}\text { Extract } \\
\text { DOC } \\
\mathrm{mg}_{\mathrm{C}} \mathrm{L}^{-1}\end{array}$ & $\mathrm{pH}$ & $\begin{array}{l}\text { Iron } \\
\mu \mathrm{M}\end{array}$ & $\begin{array}{l}\mathrm{NO}_{3}^{-} \\
\mu \mathrm{M}\end{array}$ & $\begin{array}{l}\mathrm{NO}_{2}^{-} \\
\mu \mathrm{M}\end{array}$ & $\begin{array}{l}\mathrm{SO}_{4}^{--} \\
\mu \mathrm{M}\end{array}$ & $\begin{array}{l}\mathrm{Br}^{-} \\
\mu \mathrm{M}\end{array}$ & $\begin{array}{l}\mathrm{Cl}^{-} \\
\mu \mathrm{M}\end{array}$ & $\begin{array}{c}\text { Phosp } \\
\text { hate } \\
\mu \mathrm{M}\end{array}$ & $\begin{array}{c}\text { Act. }^{e} \\
12 \mathrm{~h} \\
\mathrm{~s}^{-1} \\
\times 10^{-4}\end{array}$ & $\begin{array}{l}\text { Act. }^{e} \\
24 \mathrm{~h} \\
\mathrm{~s}^{-1} \\
\times 10^{-4}\end{array}$ \\
\hline Winter $07^{f}$ & $5.3 \%$ & 3.45 & 2.54 & 5.32 & 0.21 & 38.2 & n.d. & n.d. & n.d. & n.d. & n.d. & $\begin{array}{l}2.12 \\
/ \text { n.d. }\end{array}$ & $\begin{array}{c}2.12 \\
12.36\end{array}$ \\
\hline Winter $09^{f}$ & n.d. & 3.17 & 1.61 & 5.33 & 0.029 & 25.5 & n.d. & n.d. & n.d. & n.d. & n.d. & $\begin{array}{l}2.12 \\
\text { /n.d. }\end{array}$ & $\begin{array}{c}2.12 \\
/ 2.36\end{array}$ \\
\hline Winter $12^{f}$ & $5.0 \%$ & 2.77 & 1.72 & 5.60 & 0.062 & 26.5 & n.d. & n.d. & n.d. & n.d. & n.d. & $\begin{array}{l}1.85 \\
\text { nn.d. }\end{array}$ & $\begin{array}{c}1.85 \\
/ 2.36\end{array}$ \\
\hline Winter $18^{f}$ & $28.1 \%$ & 3.47 & 1.90 & 5.14 & 0.35 & 39.7 & n.d. & n.d. & n.d. & n.d. & n.d. & $\begin{array}{l}1.85 \\
\text { /n.d. }\end{array}$ & $\begin{array}{c}1.85 \\
/ 2.36\end{array}$ \\
\hline Winter $2+8^{f}$ & $8.3 \%$ & 1.36 & 5.82 & 5.57 & 0.35 & 192.9 & n.d. & n.d. & n.d. & n.d. & n.d. & $\begin{array}{l}1.82 \\
/ 2.37\end{array}$ & $\begin{array}{c}1.82 \\
/ 2.32\end{array}$ \\
\hline Winter $11+13^{f}$ & n.d. & 1.36 & 4.99 & 5.78 & n.d. & 47.0 & n.d. & n.d. & n.d. & n.d. & n.d. & $\begin{array}{l}1.70 \\
/ 2.37\end{array}$ & $\begin{array}{l}1.70 \\
12.32\end{array}$ \\
\hline Winter $19+20^{f}$ & $32.2 \%$ & 1.37 & 6.81 & 5.19 & n.d. & 275 & n.d. & n.d. & n.d. & n.d. & n.d. & $\begin{array}{l}1.70 \\
/ 2.37\end{array}$ & $\begin{array}{l}1.70 \\
/ 2.32\end{array}$ \\
\hline Winter $4+5^{f}$ & n.d. & 1.33 & 5.38 & 5.48 & 0.54 & 193 & n.d. & n.d. & n.d. & n.d. & n.d. & $\begin{array}{l}1.60 \\
/ 2.37\end{array}$ & $\begin{array}{l}1.60 \\
12.32\end{array}$ \\
\hline Winter $21+22^{f}$ & $11.3 \%$ & 1.32 & 3.86 & 5.78 & 0.23 & 190 & n.d. & n.d. & n.d. & n.d. & n.d. & $\begin{array}{l}1.60 \\
/ 2.13\end{array}$ & $\begin{array}{l}1.60 \\
12.36\end{array}$ \\
\hline Winter $10+16^{f}$ & n.d. & 1.51 & 2.55 & 5.31 & 0.13 & 72.4 & n.d. & n.d. & n.d. & n.d. & n.d. & $\begin{array}{c}\text { n.d. } \\
/ 2.13\end{array}$ & $\begin{array}{c}1.55 \\
/ 2.16\end{array}$ \\
\hline Winter $03^{f}$ & $5.6 \%$ & 3.1 & 2.25 & n.d. & 0.16 & 81.6 & n.d. & n.d. & n.d. & n.d. & n.d. & $\begin{array}{l}1.61 \\
/ 2.13 \\
\end{array}$ & $\begin{array}{l}1.68 \\
/ 2.16\end{array}$ \\
\hline Winter $06^{f}$ & $12.7 \%$ & 3.2 & 5.17 & n.d. & 0.26 & 110 & n.d. & n.d. & n.d. & n.d. & n.d. & $\begin{array}{c}1.61 \\
/ 2.13\end{array}$ & $\begin{array}{c}1.68 \\
/ 2.16\end{array}$ \\
\hline Winter $15^{f}$ & n.d. & 3.33 & 3.55 & n.d. & 0.12 & 289 & n.d. & n.d. & n.d. & n.d. & n.d. & $\begin{array}{l}1.61 \\
/ 2.13 \\
\end{array}$ & $\begin{array}{l}1.68 \\
/ 2.16\end{array}$ \\
\hline Urban Spring ${ }^{g}$ & n.d. & - & 3.43 & 5.54 & n.d. & n.d. & n.d. & n.d. & n.d. & n.d. & n.d. & n.d. & $\begin{array}{c}1.90 \\
/ 1.90\end{array}$ \\
\hline Rural Spring $^{g}$ & n.d. & - & 2.50 & 4.83 & n.d. & n.d. & n.d. & n.d. & n.d. & n.d. & n.d. & n.d. & $\begin{array}{c}2.03 \\
/ 2.03\end{array}$ \\
\hline $\begin{array}{l}\text { Mixed Spring } \\
g\end{array}$ & n.d. & - & 3.56 & 5.15 & n.d. & n.d. & n.d. & n.d. & n.d. & n.d. & n.d. & n.d. & $\begin{array}{c}2.09 \\
12.09\end{array}$ \\
\hline
\end{tabular}




\begin{tabular}{|c|c|c|c|c|c|c|c|c|c|c|c|c|c|}
\hline $\begin{array}{l}\text { Urban } \\
\text { Summer } 1^{h}\end{array}$ & $27.6 \%$ & - & 11.56 & 4.34 & 3 & 77 & 2.8 & 8 & 12.8 & 25.9 & 10.6 & n.d. & $\begin{array}{l}1.68 \\
/ 1.68\end{array}$ \\
\hline $\begin{array}{l}\text { Rural Summer } \\
1^{h}\end{array}$ & $29.9 \%$ & - & 13.96 & 4.11 & 0.3 & 59.6 & 2.8 & 8.4 & 13 & 25.9 & 10.6 & n.d. & $\begin{array}{l}1.68 \\
/ 1.67\end{array}$ \\
\hline $\begin{array}{l}\text { Mixed } \\
\text { Summer } 1^{h}\end{array}$ & $31.3 \%$ & - & 12.45 & 4.22 & 1.9 & 95.3 & 2.8 & 11.9 & 13.1 & 26.7 & 10.7 & n.d. & $\begin{array}{c}1.68 \\
/ 1.66\end{array}$ \\
\hline $\begin{array}{l}\text { Urban } \\
\text { Summer } 2^{h}\end{array}$ & $24.3 \%$ & - & 8.99 & 4.74 & 1 & 75.7 & 3.5 & 8.3 & 9.8 & 26.8 & 10.6 & n.d. & $\begin{array}{r}1.81 \\
/ 1.85\end{array}$ \\
\hline $\begin{array}{l}\text { Rural Summer } \\
2^{h}\end{array}$ & $27.7 \%$ & - & 11.86 & 4.54 & 3.8 & 76.1 & 3.5 & 10.7 & 12.4 & 25.7 & 10.6 & n.d. & $\begin{array}{l}1.60 \\
/ 2.01\end{array}$ \\
\hline $\begin{array}{l}\text { Mixed } \\
\text { Summer } 2^{h}\end{array}$ & $26.0 \%$ & - & 11.86 & 4.58 & 1.6 & 93.2 & 7.2 & 13.1 & 12.4 & 26.6 & 10.8 & n.d. & $\begin{array}{r}1.60 \\
/ 1.85\end{array}$ \\
\hline Mean Urban ${ }^{i}$ & $\begin{array}{l}20.9 \% \\
\pm 9.8 \%\end{array}$ & & $\begin{array}{r}6.09 \\
\pm 3.2\end{array}$ & 5.13 & $\begin{array}{l}0.89 \\
\pm 1.1\end{array}$ & $\begin{array}{c}121.7 \\
\pm 57\end{array}$ & 3.2 & 8.2 & 11.3 & 26.4 & 10.6 & & \\
\hline Mean Rural & $\begin{array}{r}25.8 \% \\
\pm 13.8 \%\end{array}$ & & $\begin{array}{l}5.74 \\
\pm 5.1\end{array}$ & 5.03 & $\begin{array}{l}0.86 \\
\pm 1.6\end{array}$ & $\begin{array}{r}87.3 \\
\pm 101\end{array}$ & 3.2 & 9.6 & 12.7 & 25.8 & 10.6 & & \\
\hline Mean Mixed & $\begin{array}{l}13.6 \% \\
\pm 8.5 \%\end{array}$ & & $\begin{array}{l}6.14 \\
\pm 4.4\end{array}$ & 5.05 & $\begin{array}{l}0.84 \\
\pm 0.8\end{array}$ & $\begin{array}{c}127.6 \\
\pm 88\end{array}$ & 5.0 & 12.5 & 12.8 & 26.7 & 10.8 & & \\
\hline Mean Winter & $\begin{array}{r}13.6 \% \\
\pm 10.7 \%\end{array}$ & & $\begin{array}{l}3.70 \\
\pm 1.8\end{array}$ & 5.45 & $\begin{array}{l}0.22 \\
\pm 0.1\end{array}$ & $\begin{array}{l}121.6 \\
\pm 95\end{array}$ & n.d. & n.d. & n.d. & n.d. & n.d. & & \\
\hline Mean Spring & n.d. & & $\begin{array}{l}3.16 \\
\pm 0.6\end{array}$ & 5.17 & n.d. & n.d. & n.d. & n.d. & n.d. & n.d. & n.d. & & \\
\hline Mean Summer & $\begin{array}{l}27.8 \% \\
\pm 2.5 \%\end{array}$ & & $\begin{array}{l}11.78 \\
\pm 1.6\end{array}$ & 4.42 & $\begin{array}{c}1.9 \\
\pm 1.3\end{array}$ & $\begin{array}{l}79.5 \\
\pm 13\end{array}$ & 3.8 & 10.1 & 12.3 & 26.3 & 10.7 & & \\
\hline
\end{tabular}

Notes: ${ }^{a}$ Table $\mathrm{S} 1$ filters were extracted in $15 \mathrm{~mL}$ ultrapure water. ${ }^{b}$ for the combined extracts, Table S1 filters were extracted individually, and the extracts combined afterwards. ${ }^{c}$ calculated using equation 11 , main text. ${ }^{d}$ calculated as final volume/ initial volume of the extracts. ${ }^{e}$ Act $=$ actinometry results in the absence of methanol/in the presence of methanol as a hydroxyl radical quencher. ${ }^{f}$ The number of the winter extracts refer to the corresponding PR sample number, e.g., Winter 07 is the extract of PR 07 filter or Winter $2+8$ is the combined extract of PR 02 and PR 08. ${ }^{g}$ Urban Spring is composed of PR $43+30+32+26+35$, Rural Spring is composed of PR $25+33+46+47+48$, Mixed Spring is composed of PR $29+39+40+41+42 .{ }^{h}$ Urban Summer 1 is composed of PRS $50+30+17+47+40$, Rural Summer 1 is composed of PRS $13+20+46+49$ +3 , Mixed Summer 1 is composed of PRS $24+38+44+18+22$, Urban Summer 2 is composed of PRS $31+36+34+41+42$, Rural Summer 2 is composed of PRS $27+7+9+8+2$, Mixed Summer 2 is composed of PRS $23+5+14+37+32 .{ }^{i}$ Mean \pm standard deviation of the mean. 
Table S3. Characteristics of the aqueous extracts and of the blanks

\begin{tabular}{|c|c|c|c|c|c|c|c|c|c|c|c|c|}
\hline \multirow[t]{2}{*}{ Name $^{a}$} & \multicolumn{2}{|c|}{$\begin{array}{l}\text { Absorbance } \\
254 \mathrm{~nm} \mathrm{~m}^{-1}\end{array}$} & \multicolumn{2}{|c|}{$\begin{array}{l}\text { Absorbance } \\
\text { 300nm m-1 }\end{array}$} & \multicolumn{2}{|c|}{$\begin{array}{c}S U V A_{254}{ }^{a} \\
\mathrm{~L} \mathrm{mg}_{\mathrm{C}}^{-1} \mathrm{~m}^{-1}\end{array}$} & \multicolumn{2}{|c|}{$\begin{array}{c}S U V A_{300}{ }^{b} \\
\mathrm{~L} \mathrm{mg}_{\mathrm{C}}^{-1} \mathrm{~m}^{-1}\end{array}$} & \multicolumn{2}{|c|}{$\begin{array}{c}S U V A_{\mathrm{avg}}{ }^{c} \\
\mathrm{~L} \mathrm{mg}_{\mathrm{C}}^{-1} \mathrm{~m}^{-1}\end{array}$} & \multicolumn{2}{|c|}{$\begin{array}{c}r \cdot \mathrm{OH}^{-1} \\
\mathrm{nM} \mathrm{s}^{-1}\end{array}$} \\
\hline & fresh & $i_{24}$ & fresh & $i_{24}$ & fresh & $i_{24}$ & fresh & $i_{24}$ & fresh & $i_{24}$ & fresh & $i_{24}$ \\
\hline Winter 07 & 2.9 & 1.91 & 1.34 & 0.7 & 1.14 & 0.75 & 0.53 & 0.28 & 0.31 & 0.11 & n.m. & n.m. \\
\hline Winter 09 & 1 & 0.8 & 0.31 & 0.26 & 0.62 & 0.5 & 0.19 & 0.16 & 0.08 & 0.05 & n.m. & n.m. \\
\hline Winter 12 & 2.99 & 1.92 & 1.28 & 0.77 & 1.74 & 1.12 & 0.75 & 0.45 & 0.45 & 0.12 & $5.1 \times 10^{-3}$ & $8.5 \times 10^{-3}$ \\
\hline Winter 18 & 1.9 & 1.23 & 0.82 & 0.47 & 1 & 0.65 & 0.43 & 0.25 & 0.19 & 0.05 & $4.4 \times 10^{-3}$ & $6.3 \times 10^{-3}$ \\
\hline Winter $2+8$ & 7.32 & 6.25 & 3.78 & 2.73 & 1.26 & 1.07 & 0.65 & 0.47 & 0.35 & 0.19 & $14.8 \times 10^{-3}$ & $17.1 \times 10^{-3}$ \\
\hline Winter $11+13$ & 2.81 & 2.63 & 0.8 & 0.65 & 0.56 & 0.53 & 0.16 & 0.13 & 0.05 & 0.08 & $6.9 \times 10^{-3}$ & $10.0 \times 10^{-3}$ \\
\hline Winter $19+20$ & 9.12 & 7.85 & 5.15 & 3.87 & 1.34 & 1.15 & 0.76 & 0.57 & 0.35 & 0.27 & $45.6 \times 10^{-3}$ & $31.4 \times 10^{-3}$ \\
\hline Winter $4+5$ & 8.85 & 7 & 4.62 & 3.01 & 1.65 & 1.3 & 0.86 & 0.56 & 0.47 & 0.21 & $22 \times 10^{-3}$ & $19.8 \times 10^{-3}$ \\
\hline Winter $21+22$ & 4.97 & 4.15 & 2.73 & 1.9 & 1.29 & 1.07 & 0.71 & 0.49 & 0.39 & 0.2 & $17.8 \times 10^{-3}$ & $19.7 \times 10^{-3}$ \\
\hline Winter $10+16$ & 1.75 & 1.35 & 0.79 & 0.57 & 0.69 & 0.53 & 0.31 & 0.22 & 0.11 & 0.06 & $11.7 \times 10^{-3}$ & $11.7 \times 10^{-3}$ \\
\hline Winter 03 & 3.85 & 3.1 & 1.91 & 1.29 & 1.71 & 1.34 & 0.85 & 0.58 & 0.47 & 0.25 & $12.3 \times 10^{-3}$ & $13.1 \times 10^{-3}$ \\
\hline Winter 06 & 10.68 & 8.32 & 6.11 & 3.75 & 2.06 & 1.61 & 1.18 & 0.73 & 0.57 & 0.25 & $42.6 \times 10^{-3}$ & $22.5 \times 10^{-3}$ \\
\hline Winter 15 & 7.02 & 5.71 & 3.95 & 2.67 & 1.98 & 1.61 & 1.11 & 0.75 & 0.56 & 0.26 & $34 \times 10^{-3}$ & $30.9 \times 10^{-3}$ \\
\hline Winter 01 (blank) & 0.37 & 1.16 & $0.15^{d}$ & 0.55 & - & - & - & - & - & - & $3.2 \times 10^{-3}$ & $7.2 \times 10^{-3}$ \\
\hline Winter 14 (blank) & 0.43 & 0.36 & $0.18^{d}$ & $0.18^{d}$ & - & - & - & - & - & - & $3 \times 10^{-3}$ & n.m. \\
\hline Winter 17 (blank) & 0.44 & 0.42 & $0.18^{d}$ & $0.18^{d}$ & - & - & - & - & - & - & $3.6 \times 10^{-3}$ & $6.2 \times 10^{-3}$ \\
\hline Urban Spring & 4.4 & 3.71 & 2.2 & 1.42 & 1.28 & 1.08 & 0.64 & 0.41 & 0.38 & 0.15 & $28.6 \times 10^{-3}$ & $26.5 \times 10^{-3}$ \\
\hline Rural Spring & 2.11 & 2 & 1.09 & 0.78 & 0.84 & 0.8 & 0.43 & 0.31 & 0.21 & 0.11 & $40.9 \times 10^{-3}$ & $44.7 \times 10^{-3}$ \\
\hline Mixed Spring & 5.16 & 4.39 & 2.87 & 1.8 & 1.45 & 1.23 & 0.81 & 0.51 & 0.43 & 0.19 & $61.3 \times 10^{-3}$ & $63.9 \times 10^{-3}$ \\
\hline Ur. Spring (blank) & 0.45 & n.m. & 0.13 & n.m. & - & - & - & - & - & - & n.m. & n.m. \\
\hline Ru. Spring (blank) & 0.58 & n.m. & 0.24 & n.m. & - & - & - & - & - & - & n.m. & n.m. \\
\hline Mix. Spring (blank) & 0.5 & n.m. & 0.12 & n.m. & - & - & - & - & - & - & n.m. & n.m. \\
\hline Urban Summer 1 & 15.8 & 12.2 & 8.9 & 5 & 1.37 & 1.05 & 0.77 & 0.43 & 0.46 & 0.17 & 1.5 & 0.069 \\
\hline Rural Summer 1 & 17.4 & 14.3 & 9.3 & 5.8 & 1.25 & 1.03 & 0.67 & 0.41 & 0.36 & 0.15 & 0.34 & 0.12 \\
\hline Mixed Summer 1 & 16 & 11.1 & 9.1 & 4.5 & 1.29 & 0.89 & 0.73 & 0.36 & 0.43 & 0.13 & 1.6 & 0.09 \\
\hline Urban Summer 2 & 10.8 & 9.1 & 5.2 & 3.4 & 1.2 & 1.01 & 0.58 & 0.38 & 0.3 & 0.14 & 0.25 & 0.05 \\
\hline Rural Summer 2 & 13.6 & 12.1 & 6.9 & 4.8 & 1.15 & 1.02 & 0.58 & 0.4 & 0.3 & 0.15 & 0.23 & 0.06 \\
\hline Mixed Summer 2 & 14.3 & 12.1 & 7.4 & 4.8 & 1.21 & 1.02 & 0.63 & 0.4 & 0.33 & 0.15 & 0.76 & 0.07 \\
\hline Mean Urban $^{e}$ & 8.08 & 6.45 & 4.26 & 2.66 & 1.46 & 1.15 & 0.76 & 0.48 & 0.41 & 0.18 & 0.267 & 0.031 \\
\hline Mean Rural $^{e}$ & 5.47 & 5.10 & 2.74 & 2.04 & 1.10 & 0.89 & 0.53 & 0.35 & 0.27 & 0.12 & 0.096 & 0.041 \\
\hline Mean Mixed $^{e}$ & 8.58 & 6.80 & 4.68 & 2.89 & 1.26 & 1.00 & 0.68 & 0.43 & 0.35 & 0.17 & 0.415 & 0.047 \\
\hline Mean Winter ${ }^{e}$ & 5.01 & 4.02 & 2.58 & 1.74 & 1.31 & 1.02 & 0.65 & 0.43 & 0.33 & 0.16 & 0.020 & 0.017 \\
\hline
\end{tabular}




\begin{tabular}{|l|c|c|c|c|c|c|c|c|c|c|c|c|}
\hline Mean Spring $^{\boldsymbol{d}}$ & 3.89 & 3.37 & 2.05 & 1.33 & 1.19 & 1.04 & 0.63 & 0.41 & 0.34 & 0.15 & 0.044 & 0.045 \\
\hline Mean Summer $^{\boldsymbol{d}}$ & 14.65 & 11.82 & 7.80 & 4.72 & 1.25 & 1.00 & 0.66 & 0.40 & 0.36 & 0.15 & 0.780 & 0.077 \\
\hline
\end{tabular}

Notes: ${ }^{a}$ for the name of the samples, please see Table S2 legend. ${ }^{a}$ SUVA $_{254}$ is the specific UV-Vis absorption coefficient (absorbance / DOC) at the wavelength $\lambda=254 \mathrm{~nm}^{b}{ }^{b}$ SUVA $_{300}$ is the specific UV-Vis absorption coefficient at the wavelength $\lambda=300 \mathrm{~nm}^{c}{ }^{c} \mathrm{SUVA}_{\text {avg }}$ is the carbon normalized amount of light absorbed in the wavelength interval 290-400nm. ${ }^{d}$ Value non-significantly different from $0 .{ }^{e}$ The calculation of the mean excluded the blanks.

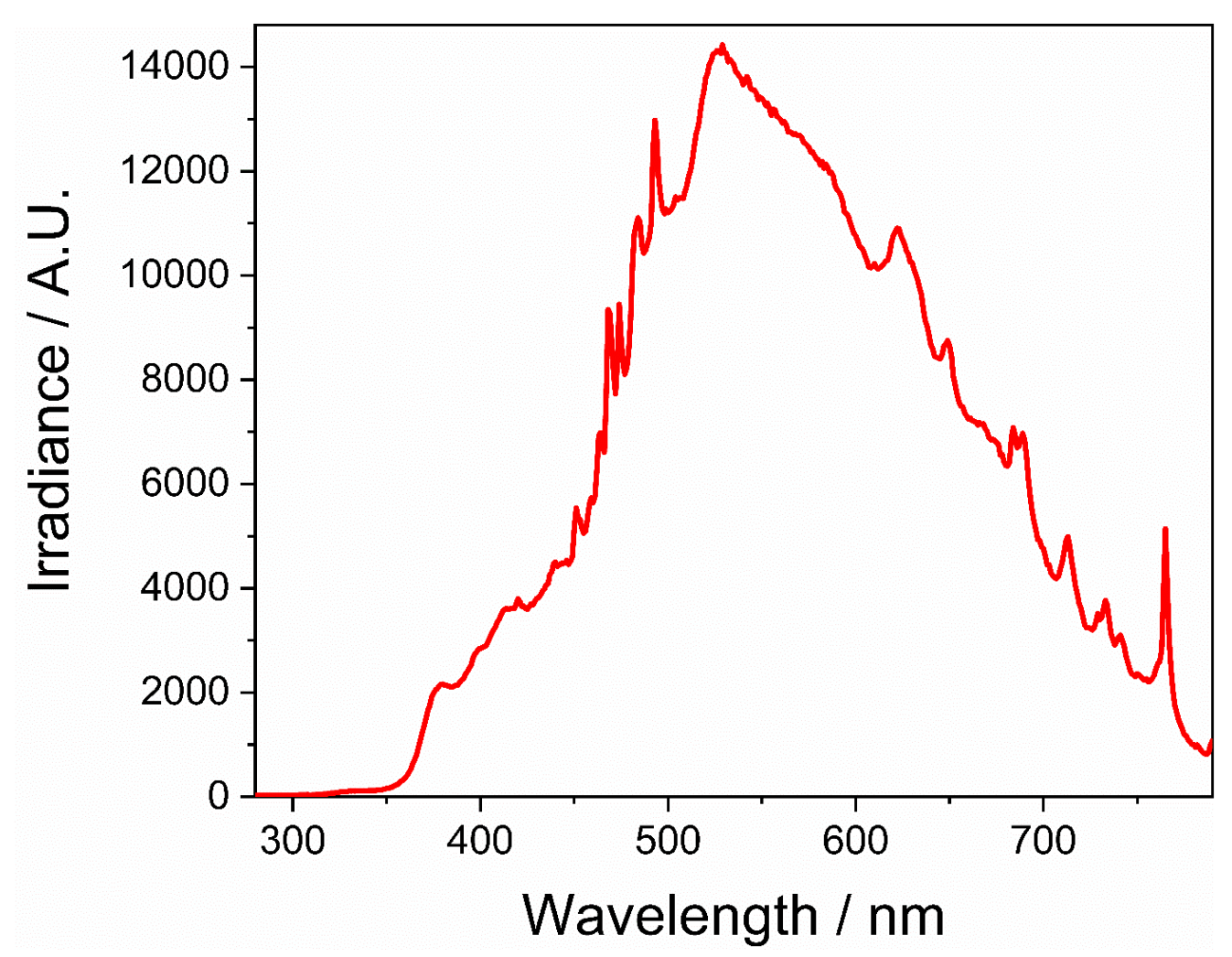

Figure S3. Photon irradiance spectra from the solar simulator in fluence based unit measured with the spectroradiometer. 


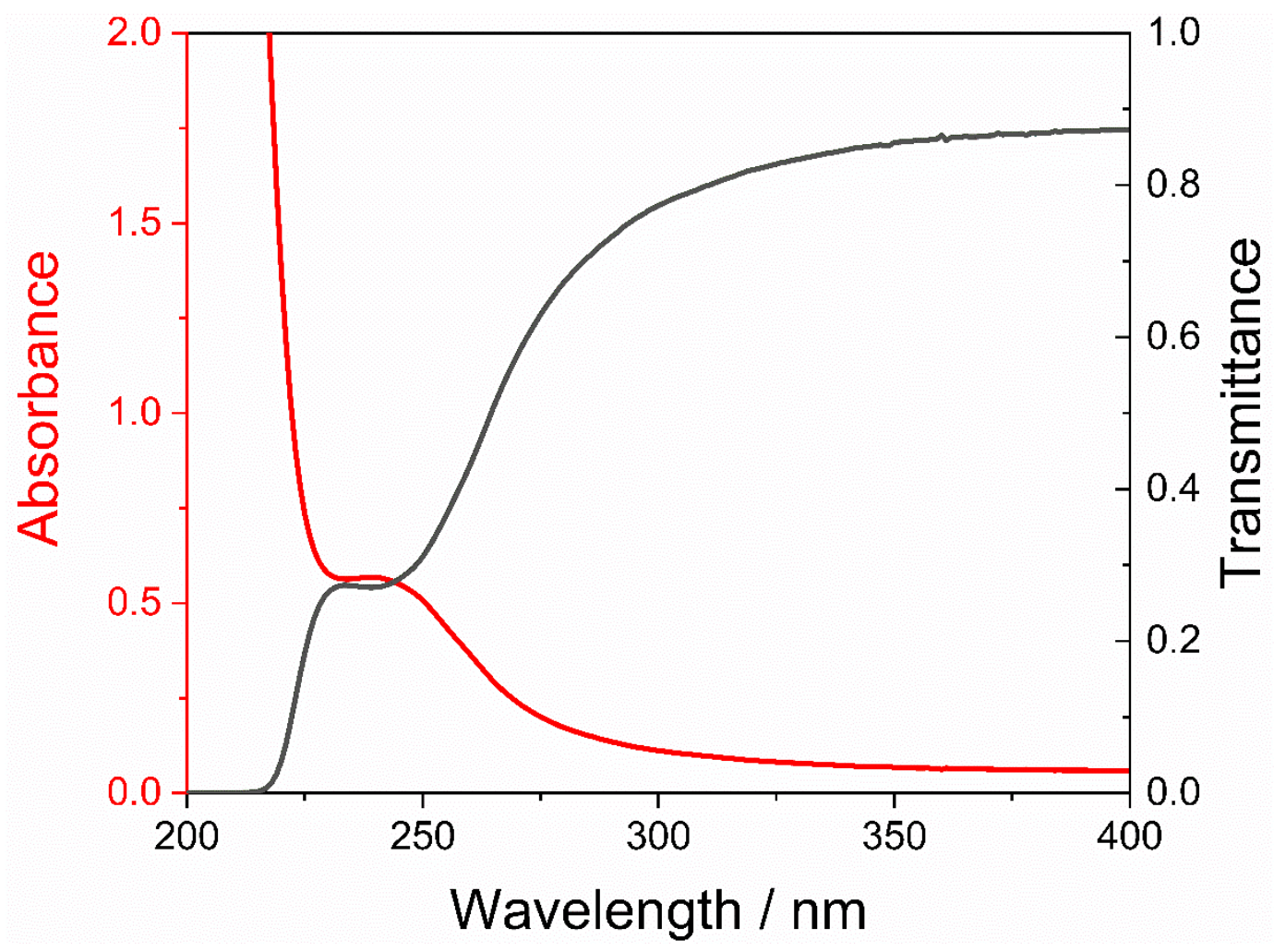

Figure S4. UV-Vis absorbance and transmittance spectra of an irradiation experiment cuvette. The measurement was done with a blank done without any cuvette in the spectrophotometer. This introduces a systematic error as the reflectance of the measurement beam on the surface of the cuvette is not corrected. 


\section{Text S1. Chemical Actinometer}

The $p$-nitroanisol (PNA)/ pyridine actinometer was used during the irradiation experiments using a concentration of $10 \mu \mathrm{M}$ of PNA and $5 \mathrm{mM}$ of pyridine. For this pyridine concentration, the quantum yield for the PNA (which depends on pyridine concentration) is of $1.74 \times 10^{-3}$. ${ }^{5} 100 \mu \mathrm{L}$ aliquots of the PNA/pyridine actinometer solutions were taken at regular time intervals (total irradiation time $\approx 4-5$ hours) and diluted with $100 \mu \mathrm{L}$ water. The PNA concentration was measured using high performance liquid chromatography (HPLC), see Table S4.

Text S2. Singlet oxygen $\left({ }^{1} \mathrm{O}_{2}\right)$ measurements

${ }^{1} \mathrm{O}_{2}$ was measured by spiking the samples with $22.5 \mu \mathrm{M}$ furfuryl alcohol (FFA) as a probe compound and $0.1 \mathrm{M}$ of methanol as an ${ }^{\circ} \mathrm{OH}$ quencher (for the samples not already containing methanol). ${ }^{6} 100 \mu \mathrm{L}$ aliquots were taken at regular time intervals (total irradiation time $=4$ hours) and diluted with $100 \mu \mathrm{L}$ water and the FFA concentration followed using HPLC and the analytical method presented in Table S4. Pseudo-first order FFA disappearance rate constants were determined by non-linear fitting to a first-order kinetic equation using the software OriginPro 2018 . $\left[{ }^{1} \mathrm{O}_{2}\right]_{\mathrm{ss}}$ was then calculated using the second-order rate constant between FFA and ${ }^{1} \mathrm{O}_{2}\left(k_{\mathrm{FFA}, 1 \mathrm{O} 2}\right)$ of $1.0 \times 10^{8} \mathrm{M}^{-1} \mathrm{~s}^{-1}$. $^{7}$ At steady state, the rate of formation of ${ }^{1} \mathrm{O}_{2}\left(r_{102}\right)$ is equal to the rate of ${ }^{1} \mathrm{O}_{2}$ disappearance and $r_{1 \mathrm{O} 2}$ was calculated using the following expression: $r_{1 \mathrm{O} 2}=\left[{ }^{1} \mathrm{O}_{2}\right]_{\mathrm{ss}} \times 2.76 \times 10^{5} \mathrm{M} \mathrm{s}{ }^{-1}$. ${ }^{7} \mathrm{The}$ quantum yield for ${ }^{1} \mathrm{O}_{2}$ production $\left(\Phi_{1 \mathrm{O} 2}\right)$ was then calculated as the ratio of $r_{1 \mathrm{O} 2}$ over the rate of light absorption.

Text S3. Hydroxyl radical ( $\left.{ }^{\circ} \mathrm{OH}\right)$ measurements

The production of ${ }^{\circ} \mathrm{OH}$ was quantified using the conversion of benzoic acid (BA) to salicylic acid (SA). ${ }^{8}$ The extracts were spiked with BA to a [BA] of $200 \mu \mathrm{M}$ using a concentrated $(\approx 18 \mathrm{mM})$ stock solution of BA that had its $\mathrm{pH}$ adjusted to the pH of the extracts. $100 \mu \mathrm{L}$ aliquots were taken at regular time intervals (total irradiation time $=5$ hours) and diluted with $100 \mu \mathrm{L}$ of a $20 \mathrm{mM} \mathrm{H}_{3} \mathrm{PO}_{4}+0.2 \mathrm{M} t$-butanol solution and the concentration of SA measured using a calibration line using HPLC and the analytical methods described in Table S4. The production of ${ }^{\circ} \mathrm{OH}$ was then calculated using the yield of SA production from the $\mathrm{BA}+{ }^{\circ} \mathrm{OH}$ reaction of $0.155 .{ }^{9}$ 
Table S4. High Performance Liquid Chromatography (HPLC) methods ${ }^{a}$

\begin{tabular}{|c|c|c|c|c|c|c|c|}
\hline Compound & Eluent & $\begin{array}{l}\text { Retention } \\
\text { time / min }\end{array}$ & $\begin{array}{c}\text { Detection } \\
\text { wavelength (UV) } \\
\text { or excitation / } \\
\text { detection } \\
\text { wavelength } \\
\text { (fluorescence) } \\
\text { /nm }\end{array}$ & $\begin{array}{c}\text { Limit of } \\
\text { detection }^{b} \\
\text { nM }\end{array}$ & $\begin{array}{c}\text { Limit of } \\
\text { quantification }^{b} \\
\mathrm{nM}\end{array}$ & $\begin{array}{c}\text { Standard } \\
\text { deviation }^{c} \\
\%\end{array}$ & $\begin{array}{l}\text { Measuring } \\
\text { range } \\
\mu \mathrm{M}\end{array}$ \\
\hline furfuryl alcohol & $\begin{array}{c}65 \% 10 \mathrm{mM} \\
\text { phosphoric acid } \\
35 \% \text { methanol }\end{array}$ & 2.9 & 219 & 75 & 250 & 0.2 & $15-22.5$ \\
\hline$p$-nitroanisole ${ }^{d}$ & $\begin{array}{c}50 \% 10 \mathrm{mM} \\
\text { phosphoric acid } \\
50 \% \text { acetonitrile }\end{array}$ & 2.3 & 300 & 5 & 16 & 0.8 & $0.3-10$ \\
\hline salicylic acid & $\begin{array}{c}70 \% 10 \mathrm{mM} \\
\text { phosphoric acid } \\
30 \% \text { acetonitrile }\end{array}$ & 6.2 & $300 / 410$ & 1.8 & 6.0 & 3.8 & 6-2000 nM \\
\hline
\end{tabular}

Note:

${ }^{a}$ All methods used were isocratic with a flow rate of $1 \mathrm{~mL} \min ^{-1}$ except otherwise mentioned. The column was kept at room temperature $\left(\approx 22^{\circ} \mathrm{C}\right)$.

${ }^{b}$ Determined using the signal/noise ratio method

${ }^{c}$ The relative standard deviation was calculated for furfuryl alcohol and $p$-nitroanisole on the mean of the $\mathrm{t}=0$ concentrations $(22.5 \mu \mathrm{M}$ for furfuryl alcohol and $10 \mu \mathrm{M}$ for $p$-nitroanisole). For salicylic acid, the standard deviation was calculated on the mean of the 5 and $10 \mu \mathrm{M}$ data points of the calibration lines.

${ }^{d}$ The flow rate was of $2 \mathrm{~mL} \mathrm{~min}^{-1}$. 
Text S5. Chemicals used in the experiments

Benzoic acid CAS N 0 : 65-85-0, Alfa Aesar, recrystalised. Salicylic acid 69-72-7, EMD, purity min. 99\%. Furfuryl alcohol 98-00-0, TCI, 97\%. p-Nitroanisole 100-17-4, Aldrich, recrystalised. Pyridine 110-86-1, Mallinckrodt chemicals, 99\%. Sodium hydroxide 1310-73-2, VWR. Phosphoric acid 7664-38-2, EMD Millipore, 85\% w/w in $\mathrm{H}_{2} \mathrm{O}$. Methanol VWR, HPLC grade. Acetonitrile, VWR, HPLC grade.

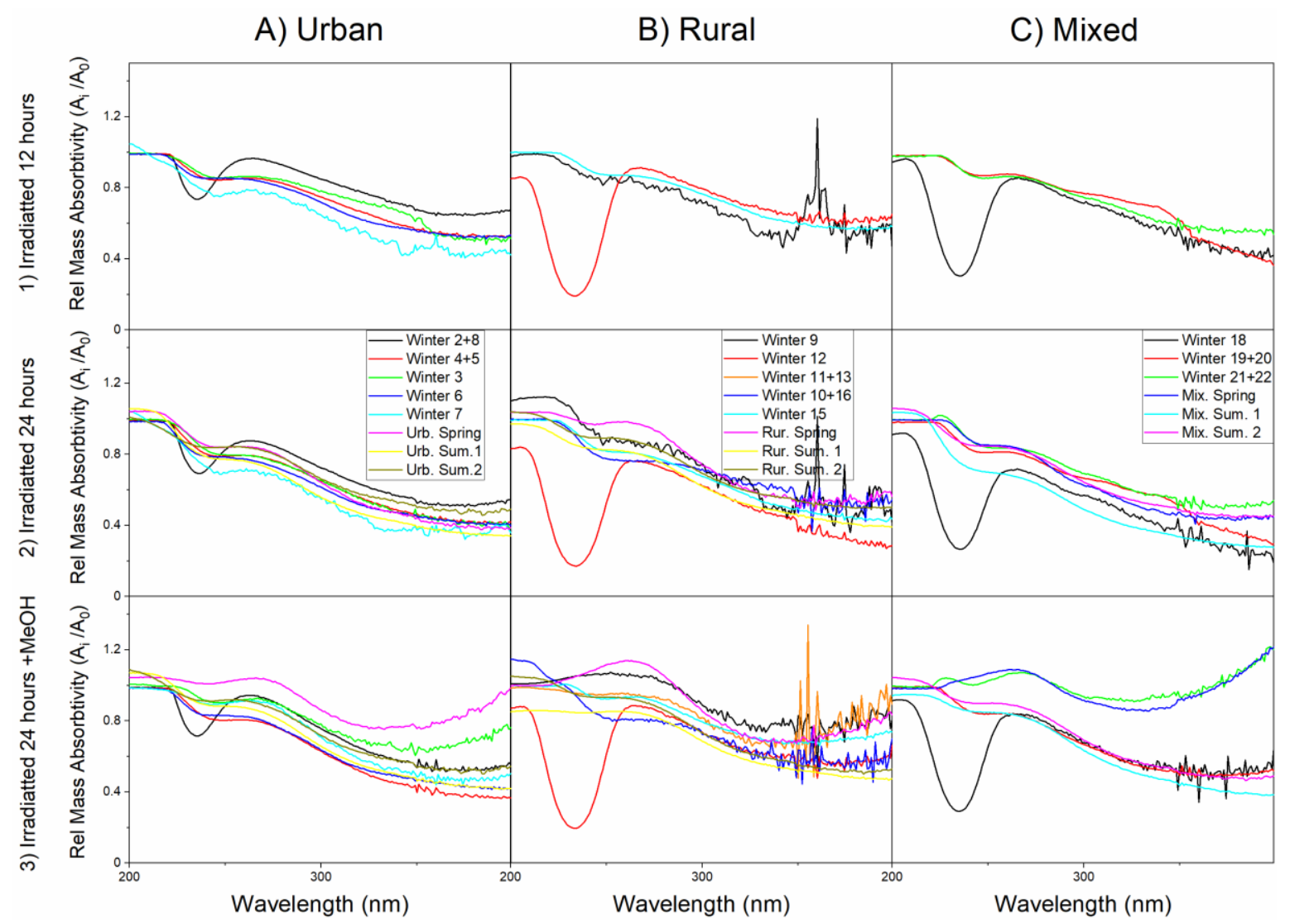

Figure S5. Effects of photoaging on the optical characteristics of the $\mathrm{PM}_{2.5}$ aqueous extracts in the presence and in the absence of $0.1 \mathrm{M}$ methanol as a hydroxyl radical ( $\left.{ }^{\circ} \mathrm{OH}\right)$ quencher. A) urban samples, B) rural samples and C) mixed urban/rural samples. Line 1) relative variation $\left(\mathrm{MA}_{\mathrm{i}=12 \text { hours }} / \mathrm{MA}_{\mathrm{i}=0}\right)$ of the mass absorptivity after 12 hours of simulated sunlight irradiation. Line 2) relative variation of the mass absorptivity $\left(\mathrm{MA}_{\mathrm{i}=24 \mathrm{hours}} / \mathrm{MA}_{\mathrm{i}=0}\right)$ after 24 hours of simulated sunlight irradiation. Line 3)

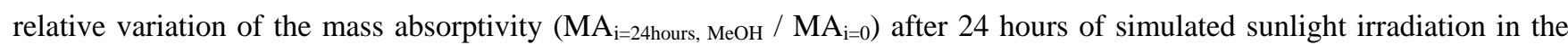
presence of $0.1 \mathrm{M}$ methanol as a ${ }^{\circ} \mathrm{OH}$ quencher. 

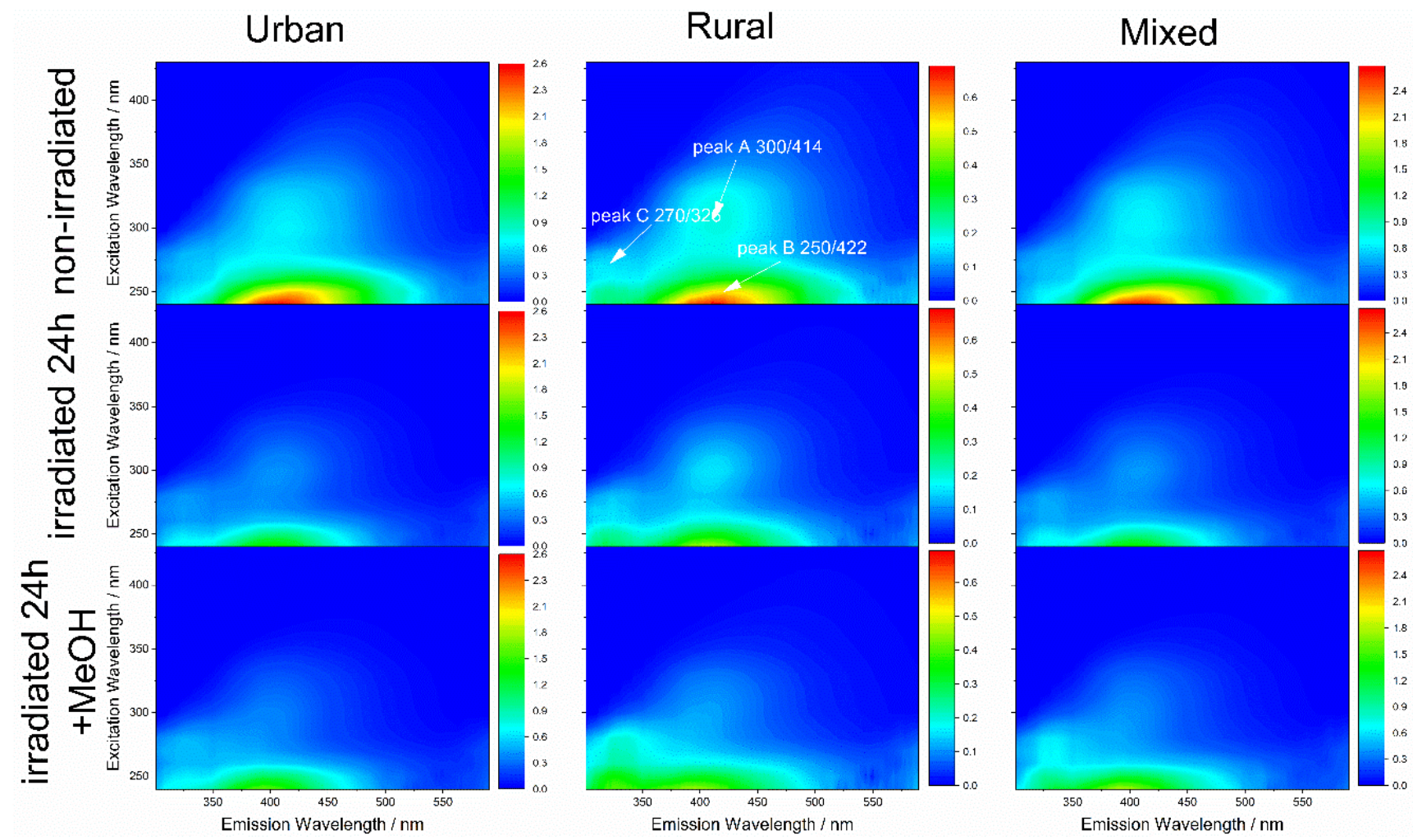

Figure S6. Effects of photoirradiation on the fluorescence excitation emission matrices (EEMs) of the spring $\mathrm{PM}_{2.5}$ aqueous extracts. Columns 1, 2 and 3 extracts from urban, rural and mixed provenance respectively. Line 1, non-irradiated $\mathrm{PM}_{2.5}$ aqueous extracts. Line 2, extracts irradiated for 24 hours. Line 3, extracts irradiated for 24 hours in the presence of $0.1 \mathrm{M}$ methanol as a hydroxyl radical $\left({ }^{\circ} \mathrm{OH}\right)$ quencher. Local peak maxima and excitation/emission wavelength are indicated on the top middle EEM. EEM intensities (colour scale) are presented in water Raman units. 


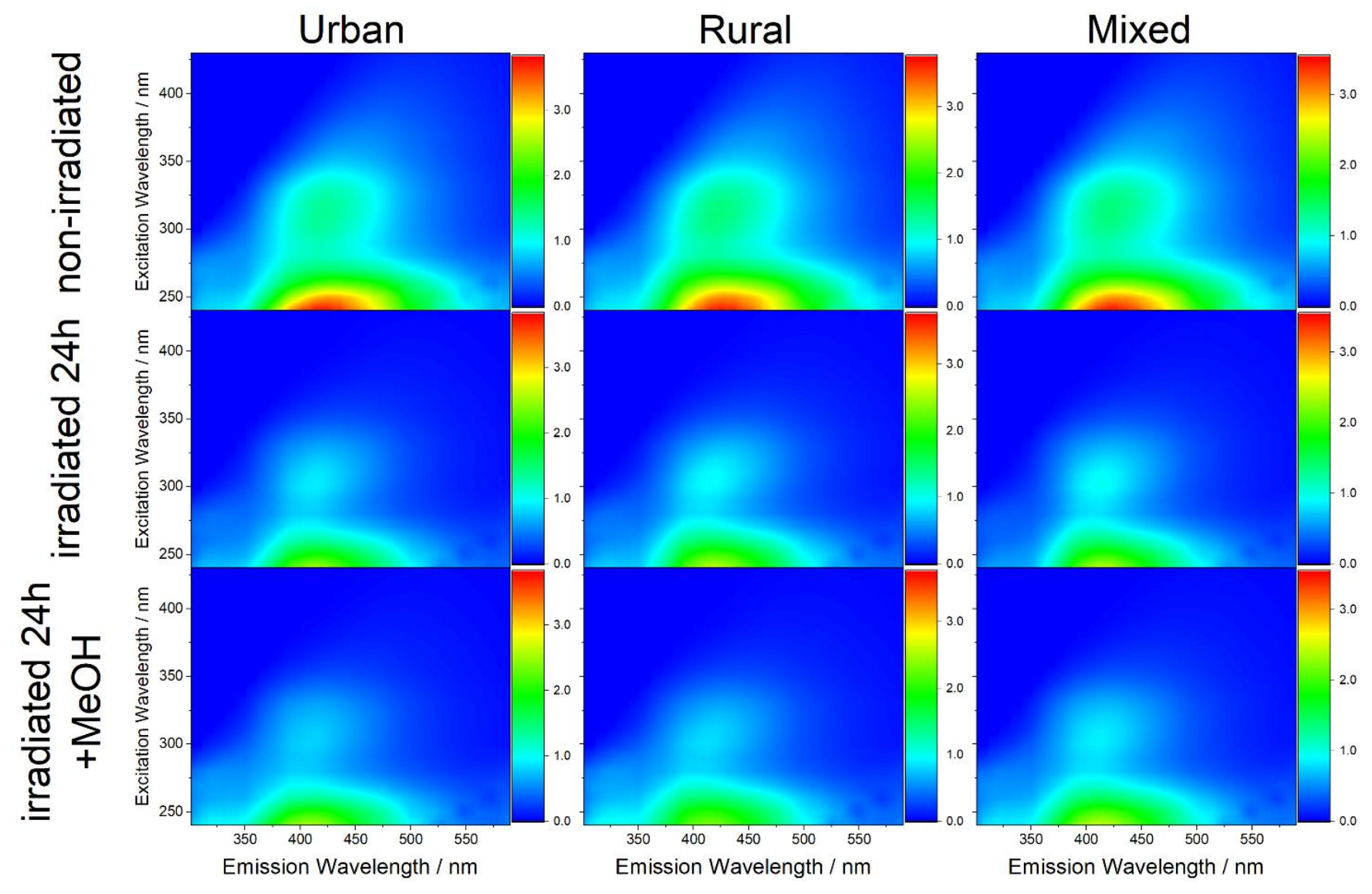

Figure S7. Fluorescence excitation emission matrices for the summer $1 \mathrm{PM}_{2.5}$ aqueous extracts. See the legend of Figure S6 for the description of the figure. 


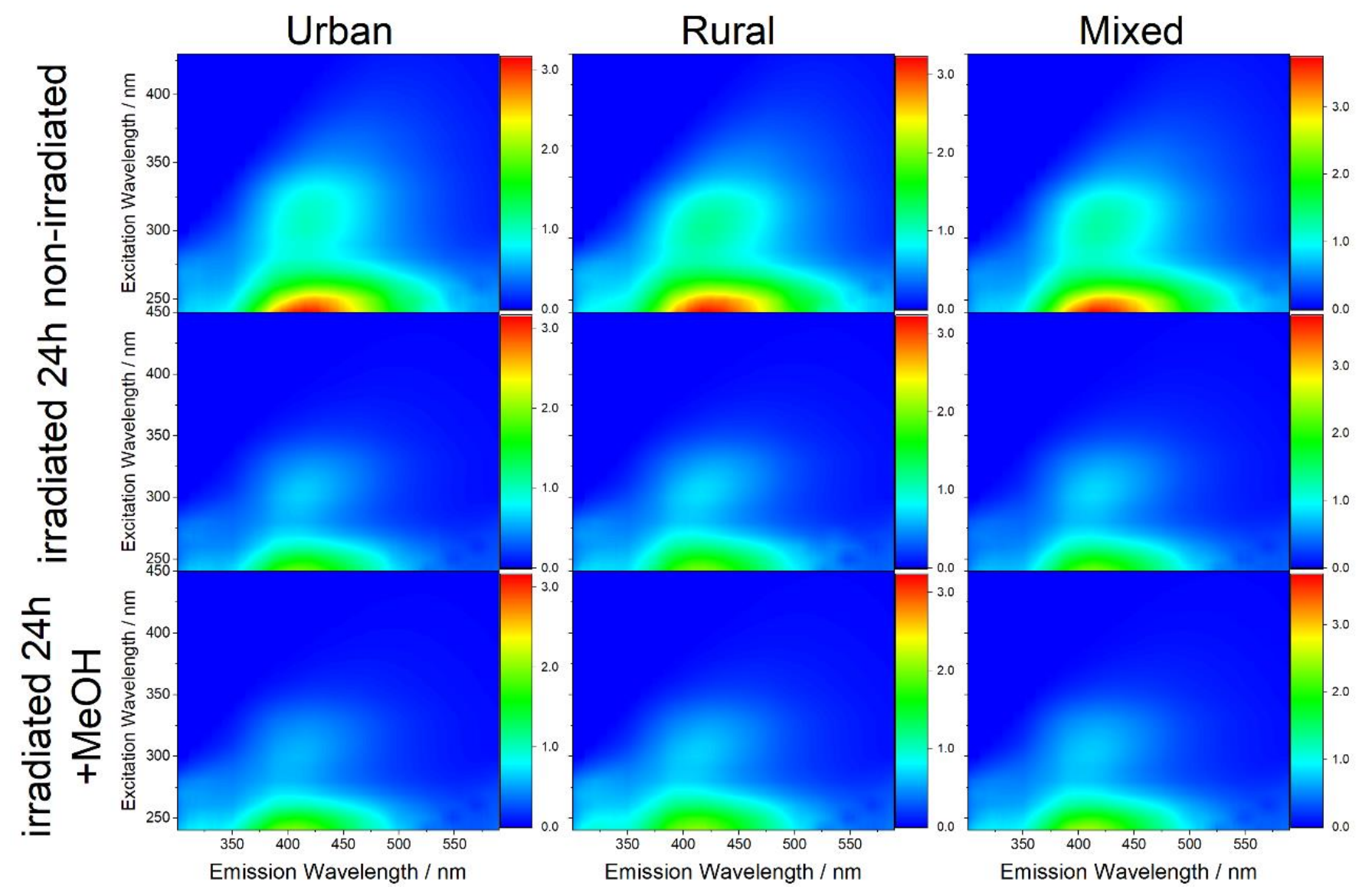

Figure S8. Fluorescence excitation emission matrices for the summer $2 \mathrm{PM}_{2.5}$ aqueous extracts. See the legend of Figure S6 for the description of the figure. 
Table S5. Mean fluorescence quantum yield $\left(\Phi_{\mathrm{F}}\right)$ and mean relative (to the fresh samples intensity) fluorescence variation for the three sampling sites and the three sampling seasons. Peaks $A=300 / 414 \mathrm{~nm}, \mathrm{~B}=250 / 422 \mathrm{~nm}$ and $\mathrm{C}=270 / 326 \mathrm{~nm}$, excitation/emission wavelength respectively. $\mathrm{I}_{0}=$ fresh samples, $\mathrm{I}_{24}=$ extracts irradiated for 24 hours, $\mathrm{I}_{24}+\mathrm{MeOH}=$ extracts irradiated for 24 hours in the presence of $0.1 \mathrm{M}$ methanol as a hydroxyl radical ( $\left.{ }^{\circ} \mathrm{OH}\right)$ quencher.

\begin{tabular}{|c|c|c|c|c|c|c|c|c|c|c|c|c|}
\hline & \multicolumn{3}{|c|}{ Urban } & \multicolumn{3}{|c|}{ Rural } & \multicolumn{3}{|c|}{ Mixed } & \multicolumn{3}{|c|}{ Mean } \\
\hline & $\mathrm{I}_{0}$ & $\mathrm{I}_{24}$ & $\begin{array}{c}\mathrm{I}_{24} \\
+\mathrm{MeOH}\end{array}$ & $\mathrm{I}_{0}$ & $\mathrm{I}_{24}$ & $\begin{array}{c}\mathrm{I}_{24} \\
+\mathrm{MeOH}\end{array}$ & $\mathrm{I}_{0}$ & $\mathrm{I}_{24}$ & $\begin{array}{c}\mathrm{I}_{24} \\
+\mathrm{MeOH}\end{array}$ & $\mathrm{I}_{0}$ & $\mathrm{I}_{24}$ & $\begin{array}{c}\mathrm{I}_{24} \\
+\mathrm{MeOH}\end{array}$ \\
\hline $\begin{array}{l}\text { Winter } \\
\text { pic } A / A_{0}\end{array}$ & 1 & 0.62 & 0.49 & 1 & 0.82 & 0.57 & 1 & 0.69 & 0.56 & 1 & 0.70 & 0.54 \\
\hline $\begin{array}{l}\text { Spring } \\
\text { pic } A / A_{0}\end{array}$ & 1 & 0.61 & 0.52 & 1 & 0.80 & 0.57 & 1 & 0.63 & 0.57 & 1 & 0.68 & 0.55 \\
\hline $\begin{array}{l}\text { Summer } \\
\text { pic } A / A_{0}\end{array}$ & 1 & 0.68 & 0.59 & 1 & 0.67 & 0.60 & 1 & 0.69 & 0.63 & 1 & 0.68 & 0.61 \\
\hline $\begin{array}{l}\text { Mean } \\
\text { pic } A / A_{0}\end{array}$ & 1 & 0.63 & 0.52 & 1 & 0.78 & 0.58 & 1 & 0.68 & 0.59 & 1 & 0.69 & 0.56 \\
\hline $\begin{array}{l}\text { Winter } \\
\text { pic } B / B_{0}\end{array}$ & 1 & 0.49 & 0.46 & 1 & 0.66 & 0.58 & 1 & 0.54 & 0.53 & 1 & 0.56 & 0.52 \\
\hline $\begin{array}{l}\text { Spring } \\
\text { pic } \mathrm{B} / \mathrm{B}_{0}\end{array}$ & 1 & 0.45 & 0.47 & 1 & 0.60 & 0.55 & 1 & 0.45 & 0.54 & 1 & 0.50 & 0.52 \\
\hline $\begin{array}{l}\text { Summer } \\
\text { pic } B / B_{0}\end{array}$ & 1 & 0.59 & 0.60 & 1 & 0.63 & 0.62 & 1 & 0.61 & 0.65 & 1 & 0.61 & 0.62 \\
\hline $\begin{array}{l}\text { Mean } \\
\text { pic } B / B_{0}\end{array}$ & 1 & 0.51 & 0.50 & 1 & 0.64 & 0.59 & 1 & 0.55 & 0.57 & 1 & 0.57 & 0.55 \\
\hline $\begin{array}{l}\text { Winter } \\
\text { pic } \mathrm{C} / \mathrm{C}_{0}\end{array}$ & 1 & 0.68 & 0.79 & 1 & 0.80 & 0.99 & 1 & 0.71 & 0.90 & 1 & 0.74 & 0.89 \\
\hline $\begin{array}{l}\text { Spring } \\
\text { pic } C / C_{0}\end{array}$ & 1 & 0.82 & 0.98 & 1 & 0.95 & 1.38 & 1 & 0.89 & 1.25 & 1 & 0.89 & 1.20 \\
\hline $\begin{array}{l}\text { Summer } \\
\text { pic } C / C_{0}\end{array}$ & 1 & 0.81 & 1.01 & 1 & 0.77 & 0.99 & 1 & 0.75 & 1.00 & 1 & 0.78 & 1.00 \\
\hline $\begin{array}{l}\text { Mean } \\
\text { pic } C / C_{0}\end{array}$ & 1 & 0.73 & 0.87 & 1 & 0.82 & 1.04 & 1 & 0.75 & 0.99 & 1 & 0.77 & 0.96 \\
\hline $\begin{array}{l}\text { Winter } \\
\Phi_{\mathrm{F}} / \%\end{array}$ & 2.39 & 1.82 & 1.59 & 1.36 & 1.46 & 1.00 & 1.79 & 1.56 & 1.23 & 1.86 & 1.62 & 1.30 \\
\hline $\begin{array}{l}\text { Spring } \\
\Phi_{\mathrm{F}} / \%\end{array}$ & 2.81 & 2.16 & 1.63 & 1.66 & 1.56 & 1.15 & 2.11 & 1.76 & 1.26 & 2.19 & 1.83 & 1.35 \\
\hline $\begin{array}{l}\text { Summer } \\
\Phi_{\mathrm{F}} / \%\end{array}$ & 1.54 & 1.45 & 1.24 & 1.47 & 1.25 & 1.13 & 1.44 & 1.43 & 1.24 & 1.48 & 1.38 & 1.21 \\
\hline Mean $\Phi_{\mathrm{F}} / \%$ & 2.23 & 1.76 & 1.49 & 1.43 & 1.41 & 1.07 & 1.73 & 1.55 & 1.24 & 1.80 & 1.58 & 1.28 \\
\hline
\end{tabular}


Text S6. Analysis of the hydroxyl radical ('OH) reaction with atmospheric waters soluble organic carbon (WSOC)

${ }^{\circ} \mathrm{OH}$ reacts with WSOC mostly by addition and by $\mathrm{H}^{\bullet}$ abstraction reactions. ${ }^{1}$ The addition reactions tend to have the highest reaction rate constants, close to the diffusion limited rate constant (e.g. ${ }^{\circ} \mathrm{OH}$ second-order reaction rate constant of $7.8 \times 10^{9}$, $4.3 \times 10^{9}$ and $3 \times 10^{9} \mathrm{M}^{-1} \mathrm{~s}^{-1}$ towards benzene, benzoic acid and toluene respectively) ${ }^{2}$ while for the $\mathrm{H}^{\cdot}$ abstraction reactions the reaction rate constants tends to be relatively lower (e.g. ${ }^{\circ} \mathrm{OH}$ second-order reaction rate constant of $9.7 \times 10^{8}, 1.9 \times 10^{9}$ and 1.9 $\times 10^{9} \mathrm{M}^{-1} \mathrm{~s}^{-1}$ towards, methanol, ethanol and isopropanol respectively $)^{2}$. The difference in second-order rate constant between unsaturated and saturated compounds containing the same number of carbons give a good idea of the difference in reactivity, the ${ }^{\circ} \mathrm{OH}$ second-order rate constant towards ethane and ethylene is of $1.8 \times 10^{9}$ and $4.4 \times 10^{9} \mathrm{M}^{-1} \mathrm{~s}^{-1}$ respectively and towards propane and propylene of $3.6 \times 10^{9}$ and $7 \times 10^{9} \mathrm{M}^{-1} \mathrm{~s}^{-1}$. The mean second-order rate constant of ${ }^{\circ} \mathrm{OH}$ towards atmospheric cloud waters was measured to be of $(3.1 \pm 1.0) \times 10^{8} \mathrm{M}_{\mathrm{C}^{-1}} \mathrm{~s}^{-1},{ }^{3}$ comparing this value with the second-order rate constant of model compounds expressed in the same units (see Table S5), it can be observed that the reactivity of ${ }^{\circ} \mathrm{OH}$ towards WSOC is similar to one of aliphatic compounds containing partially oxidized carbons such as acetaldehyde. This probably reflects the fact that the WSOC carbons are partially oxidized with an elemental composition for the isolated WSOC being composed of $\approx 50-60 \%$ (w/w) of carbon and of $\approx 30-40 \%$ of oxygen. ${ }^{4}$ As WSOC chromophores contains double bonds or conjugated cycles, it is to be expected that ${ }^{\circ} \mathrm{OH}$ have a high second-order rate constant towards them and reacts preferentially with them. 
Table S6. Comparison between the second-order rate constant of hydroxyl radical ( $\left.{ }^{\circ} \mathrm{OH}\right)$ towards atmospheric waters dissolved carbon and model compounds.

\begin{tabular}{|c|c|c|}
\hline Compound & $\begin{array}{l}\text { Second-order rate constant }{ }^{a} \\
\qquad / \mathbf{M}^{-1} \mathbf{s}^{-1}\end{array}$ & $\begin{array}{l}\text { Second-order rate constant } \\
\qquad / M_{\mathbf{C}^{-1}} \mathbf{s}^{-1}\end{array}$ \\
\hline Propylene & $7.0 \times 10^{9}$ & $2.3 \times 10^{9}$ \\
\hline Ethylene & $4.4 \times 10^{9}$ & $2.2 \times 10^{9}$ \\
\hline Benzene & $7.8 \times 10^{9}$ & $1.3 \times 10^{9}$ \\
\hline Propane & $3.6 \times 10^{9}$ & $1.2 \times 10^{9}$ \\
\hline Phenol & $6.6 \times 10^{9}$ & $1.1 \times 10^{9}$ \\
\hline Methanol & $9.7 \times 10^{8}$ & $9.7 \times 10^{8}$ \\
\hline Ethanol & $1.9 \times 10^{9}$ & $9.5 \times 10^{8}$ \\
\hline Ethane & $1.8 \times 10^{9}$ & $9.0 \times 10^{8}$ \\
\hline Fog waters & & $(6.6 \pm 3.6) \times 10^{8 c}$ \\
\hline Isopropanol & $1.9 \times 10^{9}$ & $6.3 \times 10^{8}$ \\
\hline Benzoic acid & $4.3 \times 10^{9}$ & $6.1 \times 10^{8}$ \\
\hline Mean fog and cloud waters ${ }^{d}$ & - & $(4.9 \pm 2.3) \times 10^{8 c}$ \\
\hline Toluene & $3.0 \times 10^{9}$ & $4.3 \times 10^{8}$ \\
\hline Acetaldehyde & $7.3 \times 10^{8}$ & $3.7 \times 10^{8}$ \\
\hline Cloud waters & & $(3.1 \pm 1.0) \times 10^{8 c}$ \\
\hline Marine aerosol extract & & $(3.0 \pm 2.2) \times 10^{8 c}$ \\
\hline Rain waters & & $(2.4 \pm 2.4) \times 10^{8 c}$ \\
\hline Malonate & $3.0 \times 10^{8}$ & $1.0 \times 10^{8}$ \\
\hline Acetone & $1.1 \times 10^{8}$ & $3.7 \times 10^{7}$ \\
\hline Acetate & $8.5 \times 10^{7}$ & $4.3 \times 10^{7}$ \\
\hline Citric acid & $5 \times 10^{7}$ & $7.1 \times 10^{6}$ \\
\hline
\end{tabular}

Notes: ${ }^{a}$ data from Buxton et al. ${ }^{2 b}$ calculated as the product of the second-order rate constant in $\mathrm{M}^{-1} \mathrm{~s}^{-1}$ and $12 \mathrm{~g}$ mol $\mathrm{C}^{-1}$ divided by the product of the molar mass $\left(\mathrm{g} \mathrm{mol}^{-1}\right)$ and the carbon molar fraction $\left(\mathrm{M}_{\mathrm{C}} \mathrm{M}^{-1}\right)$ of the compound. ${ }^{c}$ data from Arakaki et al. $^{3 d}$ mean value of fog waters and cloud waters, this is the value described as $k_{\cdot} \mathrm{OH}$,WsOc in the main text and used further to estimate the steady-state concentration of hydroxyl radical under simulated irradiation $\left(\left[{ }^{\circ} \mathrm{OH}\right]_{\mathrm{ss}}\right)$. 

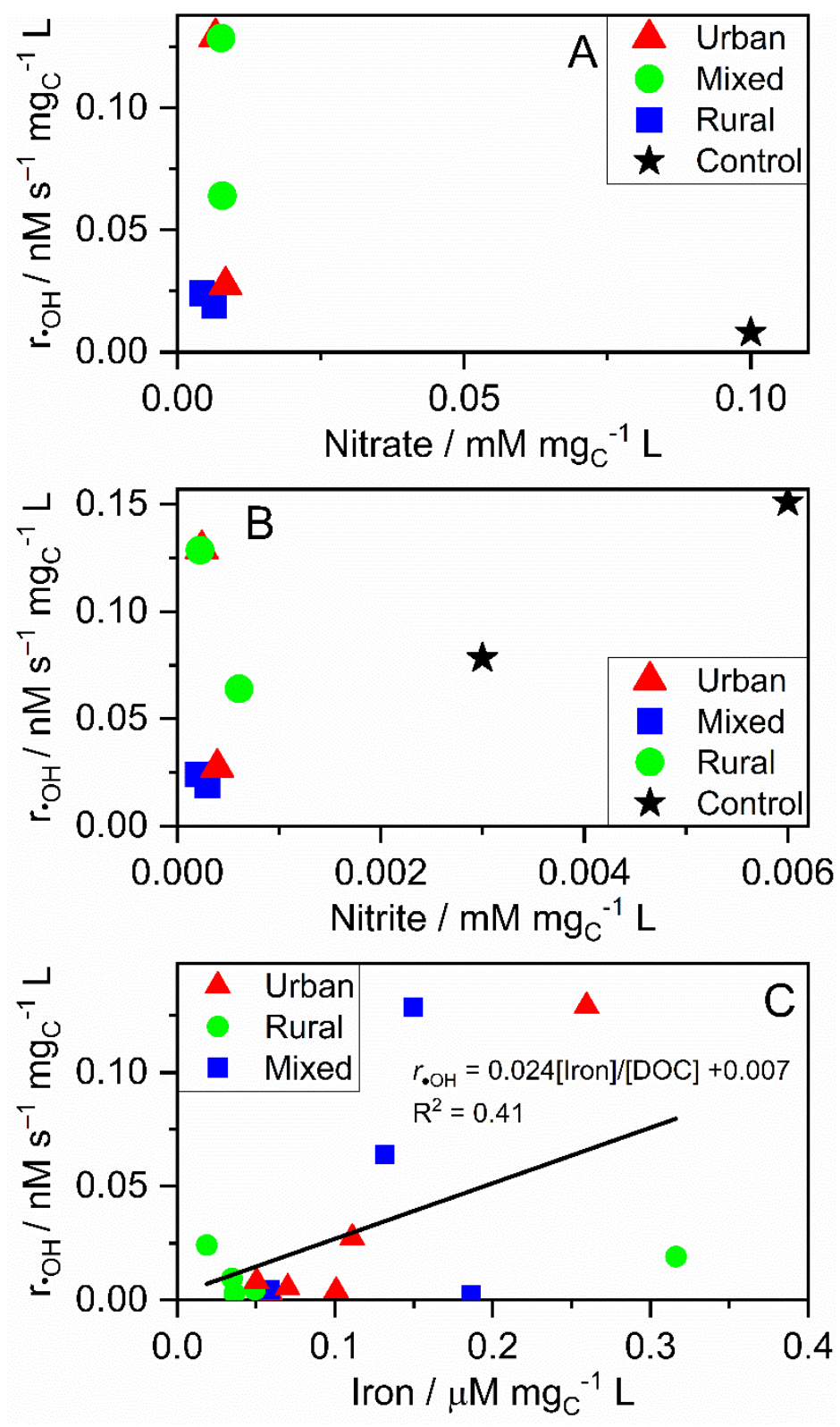

Figure S9. Rate of hydroxyl radical production $\left(r_{\cdot \mathrm{OH}}\right)$ as a function of the ions composition of the extracts. A) $r \cdot \mathrm{OH}_{\mathrm{OH}}$ vs nitrate concentration for the summer extracts (nitrate control: x-unit nM, y-unit nM s${ }^{-1}$ ). B) $r_{\cdot O H}$ vs nitrite concentration for the summer extracts (nitrite control: $\mathrm{x}$-unit $\mathrm{nM}, \mathrm{y}$-unit $\mathrm{nM} \mathrm{s}^{-1}$ ). C) $r_{\cdot \mathrm{OH}} \mathrm{vs}$ iron concentration for the summer and the winter extracts. Red triangles, extracts from the urban site. Green circles, extracts from the mixed site. Blue squares, extracts from the rural site. Black stares, control experiments using $\mathrm{NaNO}_{3}$ or $\mathrm{NaNO}_{2}$ (in ultrapure water), unit $\mathrm{nM} \mathrm{s}^{-1}$. 
Text S7. Application of the pre-equilibrium approximation for the calculation of the rate constant between ${ }^{\circ} \mathrm{OH}$ and chloride or bromide.

The pre-equilibrium approximation was used to calculate the irreversible second-order rate constant between ${ }^{\circ} \mathrm{OH}$ and chloride or bromide. The equations can be written as (all rate constant from Grebel et al. ${ }^{10}$ ):

\section{Chloride}

$\cdot \mathrm{OH}+\mathrm{Cl}^{-} \rightarrow \mathrm{HOCl}^{-}$

$$
\begin{aligned}
& k_{1}=4.3 \times 10^{9} \mathrm{M}^{-1} \mathrm{~s}^{-1} \\
& k-1=6.1 \times 10^{9} \mathrm{~s}^{-1} \\
& k_{2}=2.1 \times 10^{10} \mathrm{M}^{-1} \mathrm{~s}^{-1}
\end{aligned}
$$$$
\mathrm{HOCl}^{-} \rightarrow{ }^{\circ} \mathrm{OH}+\mathrm{Cl}^{-}
$$$$
\mathrm{HOCl}^{-}+\mathrm{H}^{+} \rightarrow \mathrm{H}_{2} \mathrm{O}+\mathrm{Cl}^{\bullet}
$$

\section{Bromide}

$\cdot \mathrm{OH}+\mathrm{Br}^{-} \rightarrow \mathrm{HOBr}^{-}$

$$
k_{1}=1.1 \times 10^{10} \mathrm{M}^{-1} \mathrm{~s}^{-1}
$$

$\mathrm{HOBr}^{-} \rightarrow{ }^{\circ} \mathrm{OH}+\mathrm{Br}^{-}$

$$
k-1=3.3 \times 10^{7} \mathrm{~s}^{-1}
$$

$\mathrm{HOBr}^{-}+\mathrm{H}^{+} \rightarrow \mathrm{H}_{2} \mathrm{O}+\mathrm{Br}^{\circ}$

$$
k_{2}=4.4 \times 10^{10} \mathrm{M}^{-1} \mathrm{~s}^{-1}
$$

$\mathrm{HOBr}^{*-} \rightarrow \mathrm{OH}^{-}+\mathrm{Br}^{\bullet}$

$k_{3}=4.2 \times 10^{6} \mathrm{~s}^{-1}$

As $\mathrm{H}^{+}$is constant, the pseudo-first order constant $\mathrm{k}_{2}$, were used, where $k_{2},=k_{2} \times\left[\mathrm{H}^{+}\right]=k_{2} \times 10^{-\mathrm{pH}}$

For bromide, $k_{2}$, reaction S7 was incorporated into $k_{2}$, and $k_{2}$, is given by the following expression: $k_{2},=k_{2} \times\left[\mathrm{H}^{+}\right]+k_{3}=k_{2} \times 10^{-\mathrm{pH}}+k_{3}$

The irreversible second-order rate $\left(k_{\mathrm{ir}}\right)$ is given by the following expression:

$k_{\mathrm{ir}}=\frac{k_{1} k_{2^{\prime}}}{k_{-1}}$ 
Table S7. Decomposition of the ${ }^{\circ} \mathrm{OH}$ reaction with the components of the summer extracts (mean of the summer samples).

-OH second-order rate constant ${ }^{\text {a }}$

$$
/ \mathbf{M}^{-1} \mathbf{s}^{-1}
$$

$4.9 \times 10^{8} / \mathrm{M}_{\mathrm{C}}^{-1} \mathrm{~s}^{-1} c$

$1 \times 10^{10}$

Nitrite

Sulfate

Iron

Bromide

Chloride

Phosphate
Mean concentration

$/ \mathbf{M}$

$1.02 \times 10^{-3} / \mathrm{M}_{\mathrm{C}}$

$79.5 \times 10^{-6}$

$3.8 \times 10^{-6}$

$10.1 \times 10^{-6}$

$1.9 \times 10^{-6}$

$12.2 \times 10^{-6}$

$26.3 \times 10^{-6}$

$10.7 \times 10^{-6}$
Fraction of ${ }^{\bullet} \mathrm{OH}$ reaction ${ }^{b}$

$(f) / \%$

88.7

6.8

0.11

4.4

0.003

0.00004

Notes: ${ }^{a}$ data from Buxton et al. ${ }^{2}$ except mentioned otherwise. ${ }^{b}$ calculated according to equation 10 , main text. ${ }^{c}$ mean of fog and cloud water values from Arakaki et al. ${ }^{3}$ (see also Table S4). ${ }^{d}$ rate constant for iron(II). ${ }^{e}$ pre-equilibrium reaction rates from Grebel et al. ${ }^{10}$, see also Text S7.

Table S8. Decomposition of the ${ }^{\circ} \mathrm{OH}$ reaction with the components of the summer extracts (see Table S7 for the mean values).

Fraction of ${ }^{\bullet} \mathrm{OH}$ reaction ${ }^{a}(f) / \%$

\begin{tabular}{lcccccc} 
& Rur. Sum. 1 & Mix. Sum. 1 & Urb. Sum. 1 & Rur. Sum. 2 & Mix. Sum. 2 & Urb. Sum. 2 \\
\hline WSOC & $90.2 \%$ & $89.6 \%$ & $89.4 \%$ & $89.1 \%$ & $83.7 \%$ & $90.0 \%$ \\
Nitrite & $4.46 \%$ & $4.97 \%$ & $5.33 \%$ & $6.5 \%$ & $12.6 \%$ & $6.81 \%$ \\
Iron & $0.013 \%$ & $0.11 \%$ & $0.18 \%$ & $0.22 \%$ & $0.09 \%$ & $0.06 \%$ \\
Bromide & $5.28 \%$ & $5.33 \%$ & $5.08 \%$ & $4.19 \%$ & $3.6 \%$ & $3.14 \%$ \\
Chloride & $0.005 \%$ & $0.004 \%$ & $0.003 \%$ & $0.002 \%$ & $0.001 \%$ & $0.001 \%$ \\
Phosphate & $3 \times 10^{-7}$ & $4 \times 10^{-7}$ & $4 \times 10^{-7}$ & $4 \times 10^{-7}$ & $4 \times 10^{-7}$ & $4 \times 10^{-7}$
\end{tabular}

Notes: ${ }^{a}$ calculated according to equation 10 , main text. 
Table S9. Singlet oxygen steady state $\left(\left[{ }^{1} \mathrm{O}_{2}\right]_{\mathrm{ss}}\right)$, quantum yield $\left(\Phi_{102}\right)$ and hydroxyl radical steady-state $\left(\left[{ }^{\circ} \mathrm{OH}\right]_{\mathrm{ss}}\right)$ for a subset of extract, nonirradiated and irradiated 24 hours in the absence and in the presence of $0.1 \mathrm{M}$ methanol as a hydroxyl radical $\left({ }^{\circ} \mathrm{OH}\right)$ quencher.

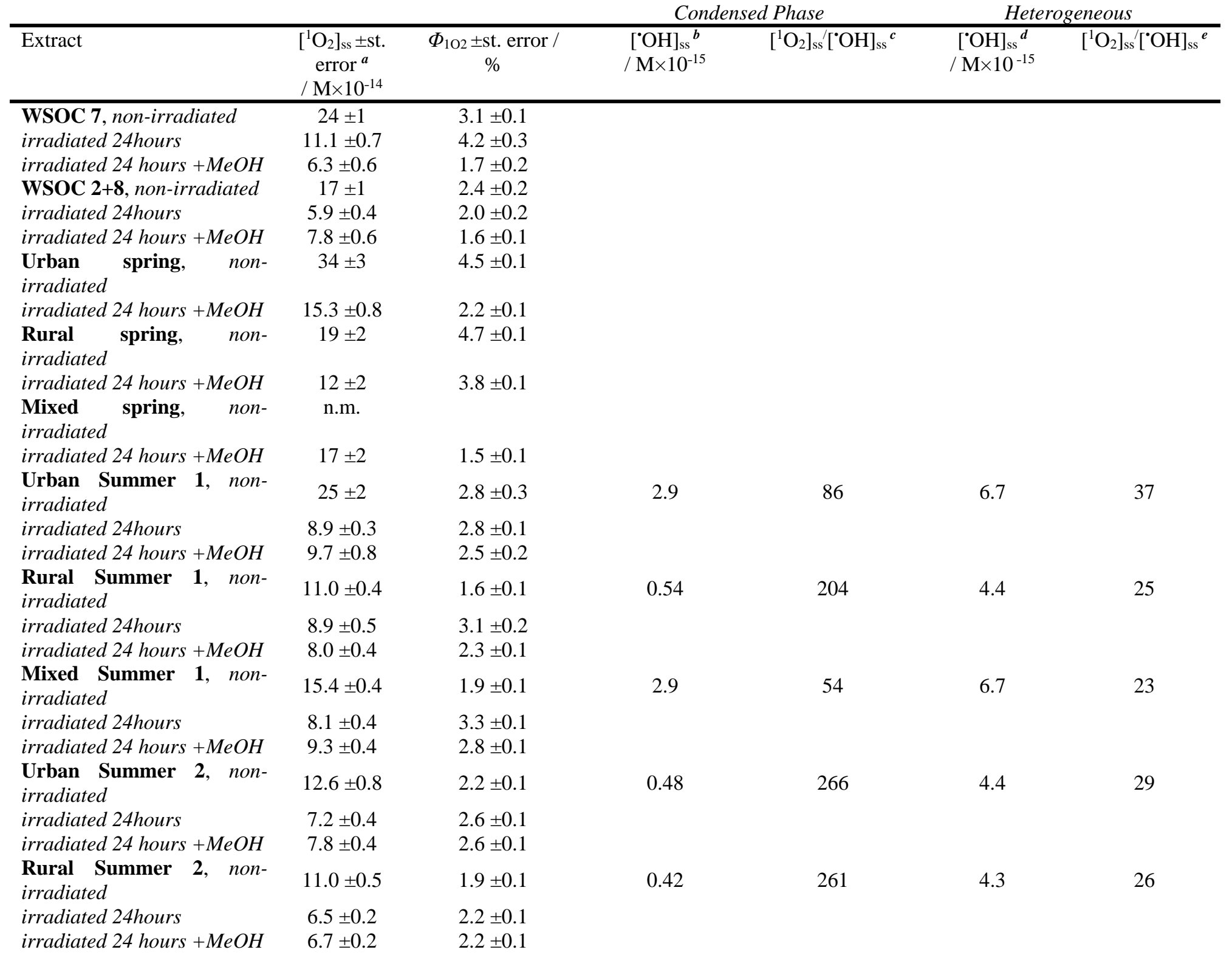




$\begin{array}{lcccc}\begin{array}{l}\text { Mixed Summer 2, non- } \\ \text { irradiated }\end{array} & \text { n.m. } & \text { n.m. } & 1.3 & 4.9 \\ \text { irradiated 24hours } & 20 \pm 3 & 7 \pm 1 & & \\ \text { irradiated 24 hours }+\mathrm{MeOH} & 8.0 \pm 0.5 & 2.6 \pm 0.2 & 1.4 & \\ \text { Mean, non-irradiated } & 19 \pm 1 & 2.8 \pm 0.2 & & 5.3 \\ \text { Mean, irradiated 24hours } & 9.6 \pm 0.7 & 3.4 \pm 0.3 & & \\ \text { Mean, irradiated 24hours } & 9.7 \pm 0.7 & 2.4 \pm 0.2 & & \\ +\mathrm{MeOH} & & \end{array}$

Notes: ${ }^{a}\left[{ }^{1} \mathrm{O}_{2}\right]_{\mathrm{ss}}$ was normalized for a [WSOC] of $11.5 \mathrm{mg}_{\mathrm{C}} \mathrm{L}^{-1}$ by multiplying the extract measured $\left[{ }^{1} \mathrm{O}_{2}\right]_{\mathrm{ss}}$ by $11.5 /[\mathrm{WSOC}] .{ }^{\boldsymbol{b}} \mathrm{Condensed} \mathrm{phase}$ $\left[{ }^{\circ} \mathrm{OH}\right]_{\mathrm{ss}}$, calculated using equation 11 , main text, the measured $r_{\cdot} \mathrm{OH}$ and a $[\mathrm{WSOC}]$ of $11.5 \mathrm{mg}_{\mathrm{C}} \mathrm{L}^{-1} \cdot{ }^{c} \mathrm{Condensed}$ phase $\left[{ }^{1} \mathrm{O}_{2}\right]_{\mathrm{ss}}{ }^{\prime}\left[{ }^{\circ} \mathrm{OH}\right]_{\mathrm{ss}}$ calculated using the Condensed phase $\left[{ }^{\circ} \mathrm{OH}\right]_{\mathrm{ss} .}{ }^{d}$ Heterogeneous $\left[{ }^{\circ} \mathrm{OH}\right]_{\mathrm{ss}}$ calculated using equation 11 and adding $2 \times 10^{-9} \mathrm{M} \mathrm{s}^{-1}$ to the measured $r \cdot \mathrm{OH}$ to account for gas transfer of ${ }^{\bullet} \mathrm{OH} .{ }^{e}$ Heterogeneous $\left[{ }^{1} \mathrm{O}_{2}\right]_{\mathrm{ss}}{ }^{\prime}\left[{ }^{\cdot} \mathrm{OH}\right]_{\mathrm{ss}}$ calculated using the heterogeneous $\left[{ }^{\circ} \mathrm{OH}\right]_{\mathrm{ss}}$ 
Table S10. Calculations of $f_{1 \mathrm{O} 2}$, the fraction of a compound that reacts with singlet oxygen $\left({ }^{1} \mathrm{O}_{2}\right)$ compared to hydroxyl radical ('OH) and half-lives of the compounds.

\begin{tabular}{|c|c|c|c|c|c|c|c|}
\hline \multirow[b]{2}{*}{ Compound } & \multirow[b]{2}{*}{$\begin{array}{c}k \cdot \mathrm{OH}, \mathrm{P} \mathbf{M}^{-1} \\
\mathrm{~s}^{-1}\end{array}$} & \multirow[b]{2}{*}{$\begin{array}{c}k_{102, \mathbf{P}} \mathbf{M}^{-1} \\
\mathbf{s}^{-1}\end{array}$} & \multicolumn{2}{|c|}{$f_{102}$} & \multicolumn{2}{|c|}{ Half-life (h) } & \multirow{2}{*}{$\begin{array}{l}\text { Reference } \\
\cdot{ }^{\circ} \mathrm{OH} /{ }^{1} \mathrm{O}_{2}\end{array}$} \\
\hline & & & $\begin{array}{c}\text { condensed } \\
\text { phase }\end{array}$ & heterogeneous & $\begin{array}{c}\text { condensed } \\
\text { phase }\end{array}$ & heterogeneous & \\
\hline Cysteine & $1.9 \times 10^{10}$ & $8.3 \times 10^{6}$ & 0.045 & 0.012 & 6.9 & 1.9 & 11 \\
\hline Indole & $1.4 \times 10^{10}$ & $4.5 \times 10^{7}$ & 0.26 & 0.086 & 7.5 & 2.5 & 11 \\
\hline Tyrosine & $1.3 \times 10^{10}$ & $8 \times 10^{6}$ & 0.061 & 0.017 & 9.9 & 2.8 & 11 \\
\hline Methionine & $1.3 \times 10^{10}$ & $1.6 \times 10^{7}$ & 0.12 & 0.034 & 9.4 & 2.7 & 11 \\
\hline Hydroquinone & $1.1 \times 10^{10}$ & $2.5 \times 10^{7}$ & 0.20 & 0.061 & 10.1 & 3.2 & 11 \\
\hline Benzimidazole & $7.9 \times 10^{9}$ & $2.5 \times 10^{6}$ & 0.033 & 0.0090 & 17.0 & 4.7 & 11 \\
\hline Benzene & $7.8 \times 10^{9}$ & $3 \times 10^{3}$ & $4.1 \times 10^{-5}$ & $1.1 \times 10^{-5}$ & 17.7 & 4.7 & $2 / 12$ \\
\hline Niclosamide & $7.5 \times 10^{9}$ & $2.3 \times 10^{7}$ & 0.24 & 0.079 & 13.9 & 4.5 & 11 \\
\hline Phenol & $6.6 \times 10^{9}$ & $3 \times 10^{6}$ & 0.046 & 0.013 & 19.9 & 5.5 & $2 / 12$ \\
\hline Imidazole & $6.4 \times 10^{9}$ & $4 \times 10^{7}$ & 0.40 & 0.15 & 12.9 & 4.9 & 11 \\
\hline Resorcinol & $5.8 \times 10^{9}$ & $2 \times 10^{7}$ & 0.27 & 0.090 & 17.4 & 5.8 & 11 \\
\hline Histidine & $4.8 \times 10^{9}$ & $7 \times 10^{7}$ & 0.61 & 0.29 & 11.2 & 5.4 & 11 \\
\hline 4-Nitrophenol & $4.1 \times 10^{9}$ & $2.5 \times 10^{6}$ & 0.061 & 0.017 & 31.6 & 8.9 & 11 \\
\hline Toluene & $3 \times 10^{9}$ & $3.9 \times 10^{3}$ & 0.00014 & $3.7 \times 10^{-5}$ & 45.9 & 12.3 & $2 / 12$ \\
\hline Isopropanol & $1.9 \times 10^{9}$ & $2 \times 10^{3}$ & 0.00011 & $3.0 \times 10^{-5}$ & 72.5 & 19.4 & $2 / 12$ \\
\hline Ethanol & $1.9 \times 10^{9}$ & $2 \times 10^{3}$ & 0.00011 & $3.0 \times 10^{-5}$ & 72.5 & 19.4 & $2 / 12$ \\
\hline Methanol & $9.7 \times 10^{8}$ & $3 \times 10^{3}$ & 0.00033 & $8.9 \times 10^{-5}$ & 142.0 & 38.1 & $2 / 12$ \\
\hline Malonate & $3 \times 10^{8}$ & $4 \times 10^{4}$ & 0.014 & 0.0038 & 452.9 & 122.7 & $2 / 12$ \\
\hline Acetone & $1.1 \times 10^{8}$ & $1.9 \times 10^{3}$ & 0.0018 & 0.00050 & 1250.4 & 335.7 & $2 / 12$ \\
\hline Acetate & $8.5 \times 10^{7}$ & $2.3 \times 10^{3}$ & 0.0029 & 0.00078 & 1616.5 & 434.3 & $2 / 12$ \\
\hline Mean & $5.4 \times 10^{9}$ & $1.4 \times 10^{7}$ & 0.15 & 0.063 & 17.9 & 5.4 & \\
\hline
\end{tabular}




\section{Bibliography for the supplementary information}

1. von Sonntag, C.; von Gunten, U., Chemistry of ozone in water and wastewater treatment: From Basic Principles to Applications; IWA Publishing: London, UK, 2012.

2. Buxton, G. V.; Greenstock, C. L.; Helman, W. P.; Ross, A. B., Critical-Review of Rate Constants for Reactions of Hydrated Electrons, Hydrogen-Atoms and Hydroxyl Radicals $\left({ }^{\circ} \mathrm{OH} /{ }^{\circ} \mathrm{O}^{-}\right)$in Aqueous-Solution. Journal of Physical and Chemical Reference Data 1988, 17 (2), 513-886.

3. Arakaki, T.; Anastasio, C.; Kuroki, Y.; Nakajima, H.; Okada, K.; Kotani, Y.; Handa, D.; Azechi, S.; Kimura, T.; Tsuhako, A.; Miyagi, Y., A General Scavenging Rate Constant for Reaction of Hydroxyl Radical with Organic Carbon in Atmospheric Waters. Environmental Science \& Technology 2013, 47 (15), 8196-8203.

4. International Humic Substances Society (IHSS), ${ }^{13} \mathrm{C}$ NMR estimates of Carbon Distribution, www.humicsubstances.org (accessed 03.IV.2018).

5. Laszakovits, J. R.; Berg, S. M.; Anderson, B. G.; O'Brien, J. E.; Wammer, K. H.; Sharpless, C. M., pNitroanisole/Pyridine and p-Nitroacetophenone/Pyridine Actinometers Revisited: Quantum Yield in Comparison to Ferrioxalate. Environmental Science \& Technology Letters 2017, 4 (1), 11-14.

6. Leresche, F.; McKay, G.; Kurtz, T.; von Gunten, U.; Canonica, S.; Rosario-Ortiz, F. L., Effects of Ozone on the Photochemical and Photophysical Properties of Dissolved Organic Matter. Environmental Science \& Technology 2019, $53(10), 5622-5632$.

7. Appiani, E.; Ossola, R.; Latch, D. E.; Erickson, P. R.; McNeill, K., Aqueous singlet oxygen reaction kinetics of furfuryl alcohol: effect of temperature, pH, and salt content. Environmental Science: Processes \& Impacts 2017, 19 (4), 507-516.

8. Leresche, F.; Torres-Ruiz, J. A.; Kurtz, T.; Gunten, U. v.; Rosario-Ortiz., F. L., Optical properties and photochemical production of hydroxyl radical and singlet oxygen after ozonation of dissolved organic matter. Environmental Science: Water Research \& Technology 2021, 7, 346.

9. Qian, J. G.; Mopper, K.; Kieber, D. J., Photochemical production of the hydroxyl radical in Antarctic waters. Deep-Sea Research Part I-Oceanographic Research Papers 2001, 48 (3), 741-759.

10. Grebel, J. E.; Pignatello, J. J.; Mitch, W. A., Effect of Halide Ions and Carbonates on Organic Contaminant Degradation by Hydroxyl Radical-Based Advanced Oxidation Processes in Saline Waters. Environmental Science \& Technology 2010, 44 (17), 6822-6828.

11. Manfrin, A.; Nizkorodov, S. A.; Malecha, K. T.; Getzinger, G. J.; McNeill, K.; Borduas-Dedekind, N., Reactive Oxygen Species Production from Secondary Organic Aerosols: The Importance of Singlet Oxygen. Environmental Science \& Technology 2019, 53 (15), 8553-8562.

12. Wilkinson, F.; Helman, W. P.; Ross, A. B., Rate Constants for the Decay and Reactions of the Lowest Electronically Excited Singlet-State of Molecular-Oxygen in Solution - an Expanded and Revised Compilation. Journal of Physical and Chemical Reference Data 1995, 24 (2), 663-1021. 